\title{
Making and Marking Relationships: Bronze Age Brandings and Mediterranean Commodities
}

\author{
Andrew Bevan
}

Postprint of chapter in Bevan, A. and D. Wengrow (eds.) 2010. Cultures of Commodity Branding, Walnut Coast: Left Coast Press.

\section{Introduction}

This chapter begins from a position of broad agreement with the idea that modern Western brands are just a particularly extreme and influential example of a cultural practice that becomes necessary in almost any economy of a certain scale where there exists a combination of mass-produced goods, aspirational consumers, and transregional systems of exchange (Fanselow 1990; Foster 2005; Hamilton and Lai 1989; Wengrow 2008). In such cases, it becomes important to find ways to reinvest otherwise standardised and deracinated products with more singular social meanings. A key point that I will seek to make, however, is that this resocialisation is most commonly achieved via the same abstract models, cultural metaphors, and practical techniques that people also use to coordinate their social relationships with one another. Branding and related behaviours, therefore, deserve to be considered more explicitly through a body of sociological theory addressing how humans structure and cue for particular types of interpersonal relationship. The discussion below begins by reviewing how relational models fit into broader anthropological and marketing theory and then considers how object values and commodity brands relate to the operation of larger scale distributed economies. The case study that then follows explores the commercial entanglement and social roles of four defining commodity types in the Mediterranean world, from the Bronze Age onwardsmetals, textiles, oils, and wine-and argues that we gain much insight into the conceptual metaphors of past societies, into modern academic debates, and into contemporary cultures of branding by approaching standardised goods from this relational perspective. ${ }^{1}$

\section{Theoretical Perspectives}

\section{Values, Brands Relationships}

When we speak of the value of an object, we introduce a semantically ambivalent but socially powerful term. In English, for example, words such as "value," "worth," and "taste" all retain a curious charge due to the fact that they evoke both what we think of as a personally ascribed or natural property and what we assume is a socially negotiated one, what we seek to keep separate from our ethical life and what we instinctively associate with moral or immoral behaviour

\footnotetext{
${ }^{1}$ Acknowledgements: My particular thanks to David Wengrow and the participants of the Anthropological and Archaeological Approaches to Commodity Branding conference for their input. In addition, John Bennet, Cécile Michel, Oliver Pryce, Sue Sherratt, and John Tait offered very useful advice on particular topics or commented on draft versions. My thanks also to the anonymous reviewers of this volume for their helpful suggestions.
} 
(Bevan 2007: 8-18). As Georg Simmel pointed out long ago (1900), value thus lies at the interface between what is perceived as objective and subjective, or, as Daniel Miller suggested more recently (2008: 1123), it is a term that people regularly use as a bridge to connect their market-led measurement of the world and a continued emphasis on the socially inalienable.

If theoretical perspectives on value have a much longer Western and nonWestern intellectual history, there have been perhaps two particularly important academic contributions over the last couple of decades. The first is an emphasis on understanding regimes of value as they change over the course of an object's full and often quite complex career, during which that object can pass through a range of production, distribution, reinterpretation, and consumption states (e.g., Appadurai 1986). The second emphasis, far more patchily promoted, has been on pulling down many of the intellectual barricades separating, for example, the perspectives on value offered by Marxist theories of embodied labour, the utility functions of classical economics, Maussian gifts, and late $20^{\text {th }}$-century consumer theory (e.g., Aswani and Sheppard 2003; Goody 2006; McGraw et al. 2003; Wengrow 2008; also Bevan 2007: 8-25).

These developments leave us much better placed to adopt unashamedly synthetic approaches to object value and to place phenomena such as commodity branding into a broader cross-cultural and diachronic context. Branding is a label that has become a rather loose metaphor for a range of stylistic phenomena and persuasive agendas, but as a point of analytical departure, it is more useful to restrict the term to the realm of broadly substitutable goods circulating as traded commodities. There has been much research devoted to the process of commodification as a form of social alienation, but more recent work on commodities has repeatedly asserted how inherently social their subsequent promotion, reception and manipulation really is. My argument here is that the processes by which a personality is reattached (for the phrase, see Foster 2005: 11) to a standardised commodity often invoke the logics used to coordinate human social relationships. In fact, there is nothing particularly new in this assertion, and a whole strain of modern consumer research has emphasised the importance of "brand personality" and "relationship marketing," with respect to such varied topics as the rebranding of modern corporations as friends or family, the personification of branded objects, the genesis of conceptual "brand communities," the consumption strategies of recently immigrated groups, or the different standards that apply to different social classes when consuming fake brands (Aaker 1997; Aggarwal 2004; Muniz and O'Guinn 2001; Oswald 1999; and Pinheiro-Machado, this volume).

Branding in the modern Western world is often about establishing bonds of trust between producer, distributor, buyer, and seller (particularly the latter two). At least initially, substitutable branded commodities are a solution to the problem of navigating the very different levels of information that each of these groups might have about the finished product and therefore to the risk of being deceived about quality or quantity (what George Akerlof [1970] famously termed a fear of "adverse selection" or of buying "lemons"). The next section discusses how this solution relates to the particular configuration of exchange in larger scale, 
distributed economies, but for now my main point is simply that this fear of deception, and desire for trust, reflects a more fundamental problem underpinning any kind of interpersonal relationship: how two or more people establish predictable ways of behaving to one another as well as consensus about the ground rules that pertain to them in a given social context. Most of the interpersonal relationships in which humans engage are understood, organised, and signalled through a limited number of basic structural logics that encourage greater levels of social coordination and consensus. This has been a conclusion shared by a large number of different economic, ethnographic, and sociological commentators, but Alan Fiske has been particularly clear in his identification of four ways in which human beings habitually think through interpersonal relationships (1991; 2004b). Depending on social context, people can choose to emphasise (1) simple, undifferentiated relationships of inclusion or exclusion (what Fiske terms "communal sharing"), (2) ordered relationships of unequal status ("authority ranking"), (3) peer-to-peer associations ("equality matching"), or (4) certain flexible kinds of metrical relationship ("market pricing").

There are good reasons for treating such distinctions as slightly more robust than just another set of anthropological or sociological types. In formal terms, they reflect four fundamental scales at which we measure the real world (nominal, ordinal, interval, and ratio) and suggest not only the evolution of certain human cognitive proclivities, but also important variations in the way these proclivities are culturally implemented (Fiske 2000; also Haslam 2004). As a set of working distinctions, they are particularly attractive given (1) the common ground they share with a wider variety of existing sociological theory (e.g., some of the distinctions raised by Douglas, Mauss, Piaget, Ricoeur, Sahlins, and Weber amongst others: Whitehead 1993: 11-12); (2) their congruence with modern cognitive theories about childhood language development and the modularity of the human mind; and (3) the balance they offer between behavioural determinism and cultural relativism (Fiske and Haslam 2000).

If we turn to the role of material culture, people can use objects to advance their interpersonal relationships in the direction of any of these different logics: Gifts, for example, do not always reflect and promote the most famous case of reciprocal exchange but can otherwise involve fairly altruistic sharing within a community, ranked differences in social status, or market-led enticements (Komter 2001; also Bevan 2007: 25-26). Rather, it is the diversion of objects from one kind of socially agreed relationship with people to another that is usually the stuff of moral outrage (particularly the commodification of things in seemingly inappropriate ways; see Appadurai 1986: 14-16; Kopytoff 1986; McGraw and Tetlock 2005; McGraw et al. 2003; Tuk et al. 2009), and arguably the main reason for the semantic ambivalence of value/values in the first place.

More importantly perhaps, certain kinds of objects are much more likely to encourage certain kinds of social relationship than others, and material culture is one important way in which people's preferred relational logics are made physically manifest and socially constituted as norms (Fiske 2004a; indeed these physical manifestations are usually the ways that such patterns are recognised by children, outsiders, or anthropologists). For example, communal, categorical 
models for social relationships are often promoted by food-sharing paraphernalia, by emblematic body modification (and its representation on artefacts), by acts of physical intimacy (and associated objects), by initiation rites, and by purity laws or taboo. Ranked relational models are commonly established via physical props that choreograph social encounters in ordered, asymmetric ways (above/below, in front/behind, before/after, bigger/smaller, stronger/weaker). They can also be reinforced by the perceived natural hierarchy of material goods (e.g., Mauss and Durkheim 1963: 83-84). Peer-topeer relationships of equivalence are usually forged and reinforced by objects that facilitate balanced, turn taking, or complementary contributions. Marketpricing logics tend to be encouraged by objects that facilitate easy convertibility and mensurability (e.g., those with bullion value), propositional offerings (e.g., samples), brand mnemonics, and accounting symbols (e.g., logos, labels, seals, and weights).

These physical propensities therefore suggest that object styles might be subject to both direct and indirect selection based on their suitability for certain kinds of social relationship, and hence that we might hope to identify the occasional residues of past relational models in the patterning of the material record. If we return to the case of modern Western commodity brands, some products make relatively straightforward, metrical claims about product efficacy (particularly those associated with a fairly early phase of advertising strategy; see Holt 2002: 80-81): For example, buy this soap and clean 50\% more dishes. In other cases, the proposition is less precise but still metrical: Wear these clothes and have more friends. However, a distinctive feature of many branded commodities is that, while they are clearly created to streamline market-led relationships between people (by providing more standardised and recognisable quantities and qualities that alleviate fears of adverse selection), their brand image or brand personality often straddles one or more of Fiske's other three relational models (i.e., communal sharing, authority ranking or equality matching), whether so engineered by marketing specialists or due to the creative contributions of consumers. This relational dexterity, often involving some kind of unspoken proposition, is a direct analogue to "indirect speech," where the use of veiled language avoids awkward mistakes in relationship coordination and/or can propose changes to existing relationships without incurring the full penalty of outright rejection (e.g., the language of bribes, half-spoken threats, and sexual come-ons; see Pinker et al. 2008).

\section{Distributed Economies}

Object value is clearly more malleable for some individuals, groups, and institutions than for others (Appadurai 1986: 31; Molm et al. 2001), and the overall social network within which such valuation occurs is an important structuring feature (e.g., Watts and Strogatz 1998). Many commentators have noted the importance of modern, hi-tech communication-cheap, fast, often literate, high-volume, long-distance-to what we think of as modern branding, including its ability to support new and often more ephemeral forms of entertainment, experience, community, and personal identity (Janson 2002; Muniz and O'Guinn 2001; Wallendorf 2001). However, while retaining an awareness that there is likely to be something unusual about the levels of 
branded material culture, branded spaces, and branded human identities present in the Western world of the last 50-100 years, we should really seek to place this in a much wider context with respect to information flow in a variety of different kinds of economy (e.g., Appadurai 1986: 48; Fanselow 1990; Hamilton and Lai 1989). The key issue is arguably the impact of drawn-out networks of production, exchange, and consumption. Indeed, although this used to be a less emphasised feature of modern brands, it has come rapidly back into fashion with an emphasis on "sourcing" by brand managers and anti-globalisation campaigners alike (Foster 2005: 11-12).

More broadly, we can associate these networks with the economies that have coalesced around sedentary, often highly urbanised societies in only a few parts of the world, particularly those that have developed transregional systems of exchange. In such circumstances, producers, distributors, and consumers become separated from one another both physically and culturally, and the propositional information that they might wish to exchange is navigated through a series of communication bottlenecks. While one-off luxury products occasionally retain elaborate biographies (real or imagined) as they pass through such bottlenecks, the same trick is rarely feasible for most goods.

The problems that this leads to are well known (e.g., Akerlof 1970; Richardson 2008): In many instances, consumers have far less knowledge about the potential range in quality of particular merchandise than the producers or distributors. Likewise, the conditions of sale or the nature of the object can often make it difficult to evaluate key properties such as durability, safety and effectiveness before purchase. Depending on their means, people may also not be able to afford to replace defective or otherwise poor purchases. This lack of economic flexibility tends to make them risk averse, but also often leaves them unable to test a seller's reliability through the trial and error of repeated purchase (though this depends on the goods involved). In many circumstances, there is also no easy or affordable legal recourse for those who have received defective goods. Finally, there are many incentives for producers and distributors to cut costs wherever possible.

In the face of these problems, commodity standardisation is an attractive solution, particularly if it is easily identifiable by the presence of some highly recognisable, carefully structured packets of cultural meaning. These mnemonic packets are usually created through physical addition to the objects involved (logos, labels, seals, special additives, and/or assembly practices), abstract symbolism, external advertisement, and, where possible, structured social performance, and thereafter are an efficient means of reinvesting standardised goods with more potent social identities (Foster 2005; Wengrow 2008).

In addition, we might also talk about three further interesting patterns associated with such systems. The first can be summarised by the English phrase "coals-to-Newcastle" (e.g., Fuller 1840: 542) and evokes the idea of trade in directions that seem senseless or uneconomical because of the superabundance of that particular commodity at the trade destination. Indeed, the Classical version of this phrase, "owls to Athens" (e.g., Aristophanes' Birds 301) is even 
neater because it refers, on the one hand, to the patron bird of the city, the associate of the goddess Athena, that roosted in the early Parthenon, and, on the other, probably also to slang for the abundant silver coins minted by Athens with a depiction the Athenian owl (hence, why take such owls to Athens where there were so many already?). In any case, a related, but structurally distinct phenomenon is the one in which an uneven geographic spread of technical knowledge, organisation, and labour that allows well-positioned intermediaries to add value to commodities in some manner (even if only through repackaging) and then pass them on to third parties or sometimes even back to the original source (e.g., Wengrow 2008: 11; Wilk 2006: 97). This is the foremost analytical feature of a "world-system," as originally formulated (Wallerstein 1974), in which very asymmetric economic relationships exist between core economic zones and their peripheries, based on a supra-territorial division of labour. Interestingly, there are plenty of examples of coals-to-Newcastle situations where these organisational asymmetries do not exist and where, instead, the key is in successful product differentiation (see below).

A second interesting feature of such economies is the charisma of standardised languages of practical efficiency and/or of elaborate consumer knowledge (Wengrow 2008: 8; see also what Michael Silverstein [2006: 493] calls "-onomic" knowledge). Luxury comestibles are a group of products for which this becomes particularly important: modern wine-talk, oil-talk, food-talk, and coffee-talk, for example, all have their own specialised terminologies, cultural authorities, and revered production practices. To varying degrees, they all share a semi-religious emphasis on provenance ("terroir," often with an emphasis on single estate products), timeliness (vintage, occasional production), the dialectic of technology and tradition (specialist equipment, secret recipes, authentic procedures), the long genealogy of the producer, and a specific jargon of production, distribution and consumption (Beverland 2005; Heath and Meneley 2007; Manning 2008). I will return to some of these features with respect to the marketing of Bronze Age oils and wine below.

A third interesting pattern associated with large-scale distributed economies can be loosely termed "leakage." While there are usually directional, carefully managed commodity flows in such economies and carefully drawn-up commercial and ideological agendas, there are also ways in which physical goods, skills, and brand abstractions escape from these channels into altogether different and often more informal contexts. This leakage is not an epiphenomenon, but a fundamental feature. For example, branded goods are often reinterpreted by consumers on their own terms, rather than the distributors. The reality of this practice and, for some, its ultimate desirability, is reflected in recent marketing initiatives that seek to influence only loosely the contexts in which goods are consumed, thereby leaving room for consumer innovations that might add further brand value (Arvidsson 2005: 243-44; Holt 2002). Likewise, branded goods are often recirculated as gifts or on the secondhand market in ways that feed back into their original value (A. Clarke, this volume). Sometimes this practice can overlap with the previous one in the physical reworking of branded objects to fit new consumer agendas (e.g., the intergenerational transfer of cut-off jeans; Hammer, this volume). Finally, brands 
often suffer from another kind of leakage when they are substituted for copies (see also both Crăciun and Pinheiro-Machado, this volume). The prepackaging and sealing practices associated with branded commodities are quality and quantity controls that reduce the risk of adverse selection, but they remain, like other efficient forms of communication (e.g., digital networks, genes) vulnerable to dissimulating free-riders: In a sense, imitation is a great indication of a (temporarily) successful brand.

\section{A Protohistorical Perspective}

Many of the theoretical approaches discussed above were developed with reference to modern Western practices or were derived from detailed anthropological fieldwork, with all of the rich levels of meaning that such research contexts provide. There is a danger, of course, that in turning to an archaeological case study, we become frustrated ethnographers (Shennan 2002: 9), attempting thick description but failing to substantiate it. The emphasis here, therefore, is placed on a proto-historic case-primarily the eastern Mediterranean in the $2^{\text {nd }}$ millennium BC, but with a wider scope when necessary-that offers a rich combination of archaeological, textual, and iconographic information. This region and time period has been something of an intellectual battleground across which many of the major sociological, anthropological, and economic theories of the $20^{\text {th }}$ century AD have been deployed in the hope of providing a decisive, ancient victory.

The urban growth and cultural expansion of $4^{\text {th }}$-millennium Mesopotamia was responsible for a pattern of city states, transregional linkages, and more standardised commodities that has had a profound and long-lasting impact on the history of the Middle East, Central Asia, Europe, and the Mediterranean (Wengrow 2008). The late $4^{\text {th }}$ and $3^{\text {rd }}$ millennia BC also see complex political, economic, and social structures emerging in the eastern Mediterranean alongside patterns of long-distance trade that became both more intensive and more unevenly felt with the increased use of donkeys for overland transport and the gradually expanding use of sailing ships. By the $2^{\text {nd }}$ millennium $\mathrm{BC}$ (the main focus here), the eastern Mediterranean region (Figure 2.1) was broken up into a relatively well-defined set of polities. These took various shapes and sizes, but were typically under the direct rule of a king, and increasingly by the end of this period, under the indirect influence of a "Great King." Immediately below the royal family was usually a small and potentially factional, upper elite group that included extended family members and a range of other powerful individuals, typically from established aristocratic lineages. Many of these people enjoyed overlapping official roles as administrators, courtiers, priests, traders, and patrons. Beneath this group in the social hierarchy there was usually a wider, lower elite group that held lesser bureaucratic posts and/or were less wellconnected provincial figures. Beyond them was the rest of the urban and rural population whose archaeological and documentary visibility varies enormously. 


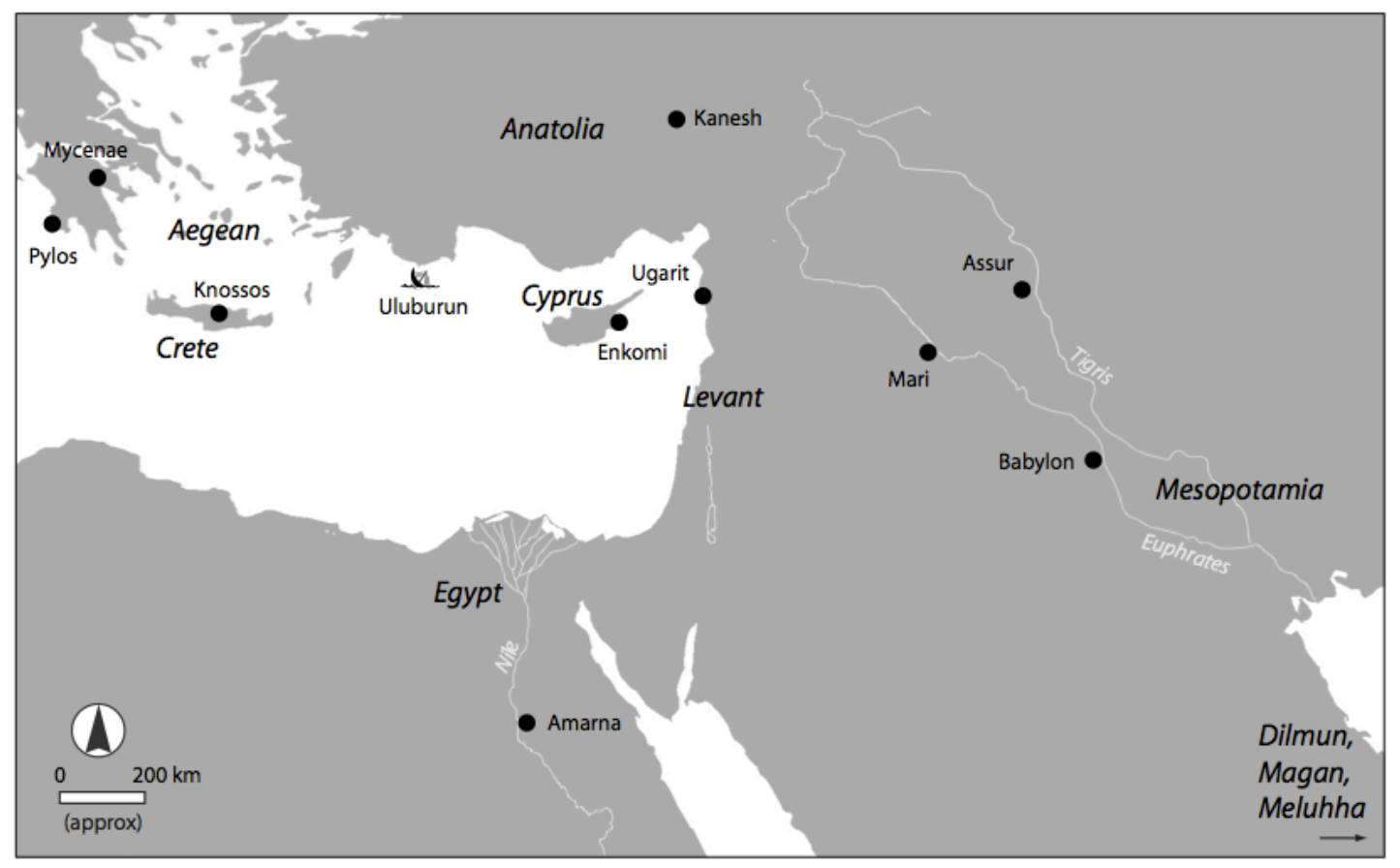

Figure 2.1. The eastern Mediterranean and Middle East with a list of places and regions mentioned in the text.

In terms of exchange, we see a marked increase in the range and quantity of goods circulating across this area over the course the Bronze Age (roughlyspeaking the $3^{\text {rd }}$ and $2^{\text {nd }}$ millennia BC: for an overview see Bevan 2007: 30-38; Sherratt and Sherratt 1991). Overall, we can document a pattern of expanding cultural and economic influence, westwards out of the core urbanised zones of Egypt and Mesopotamia and thereafter into the Levant, Anatolia, and the Aegean. Metals were a geographically restricted resource that were one of the driving factors behind long-distance exchange (e.g., Sherratt 1993), but textiles, oils, and wines were also important interregional trade goods, and, as we will see below, were commodities that travelled hundreds of kilometres despite the fact that they could, in principle, have been made anywhere in the region. These longer distance linkages encouraged an increasingly shared set of elite symbols. Counterfeits of popular commodities were very common, whether these were impressive synthetic versions such as "lapis lazuli of the kiln" rather than "lapis lazuli of the mountain" (i.e., blue glass instead of real lapis; see Oppenheim et al. 1970: 10-11) or merely cheap local copies. Indeed, imitations are present at all levels of the value hierarchy with, for example, plenty of evidence for copies of popular, but seemingly low value pottery styles (also see below with respect to oil and wine).

One clear sign of this sharing of goods and ideas were weights and measures. From at least the mid- $3^{\text {rd }}$ millennium onwards in the eastern Mediterranean and Aegean, we see evidence for both regional systems of measurement and a familiarity with the points of convergence between them (Alberti and Parise 2005; Michailidou 1999; Pulak 2000; Rahmstorf 2006). These developments probably begin slightly earlier in Mesopotamia, during the $4^{\text {th }}$ millennium, but in all cases, the evidence for standard weight systems co-appears with the evidence for more elaborate sealing practices and more standardised containers, 
suggesting, in each case, not only the up-scaling of administrative practice but also important changes in the relationship between society and material culture (Wengrow 2008).

By the later $2^{\text {nd }}$ millennium in the eastern Mediterranean, there are even stronger patterns of metrical convergence and hybridisation, particularly in the northern Levant and northern Mesopotamia. Multiple systems of weights are found at the same site or on the same shipwreck, and the documentary evidence shows them together in everyday use by the same trader. Interoperable units of weight and capacity both facilitated and reflected a period of multi-language diplomacy, polyglot mobile communities, and deliberately cosmopolitan styles in a range of material culture, all of which encouraged neater, more syncretic packets of shared meaning in language, religion, and economic life. The major metric units in almost all areas of the eastern Mediterranean and Aegean were similar and often reference notional, practical measures such as a "donkey-load" or a "fleece." These allowed producers, distributors, and consumers to talk in counts of standard commodities rather than complex weighed measures and carefully described goods (see also Sherratt and Sherratt 1991: 362-63).

The language of both diplomacy and commerce had also become relatively uniform by the $2^{\text {nd }}$ millennium BC (arguably, it was first established much earlier during the urban revolution in $4^{\text {th }}$-millennium Mesopotamia) and at its heart was a conceptual metaphor of the family and small village that was used to articulate far more complex relationships (Liverani 2000; Silver 1995: 50-53). Rulers referred to their entire kingdom as a royal household and estate (without implying control or ownership over it in a practical, everyday sense), and beyond this, carefully ranked their relations with other kingdoms, treating some as potential equals ("brothers"), others as vassals or superiors ("son," "father").

Likewise, commercial businesses were often organised around a real family, but wider partnerships with nonkin were very common, and the overall practice of commerce was choreographed through the language of colleagues-as-brothers, enticements-as-gifts, and firms-as-houses. This past conceptual framework that refers to more complex relationships in terms of the family and village has, ironically, wrought havoc with our interpretative models of Bronze Age economy and society. We have either conceived of this world as a kind of abstract, premodern "other" where temples and palaces were nodes of redistribution, objects moved in circuits of reciprocal gifting and private transactions were very limited, or have assumed that we can simply read off past economic activities using Western capitalist "common sense" about likely profit motives, object valuation, and business organisation. Perhaps the most famous version of this debate involves either agreement or disagreement with Karl Polanyi's suggestion (1957) that markets were largely absent from Bronze Age economies, but we can see similar academic fault lines running through much of the social sciences over the past 50 years.

Perhaps the best example of this, but by no means the only one, comes from the $14^{\text {th }}$-century BC diplomatic archive found at Amarna in Egypt (Moran 1987). This set of letters includes correspondence between the Egyptian pharaoh and his 
clients in Egyptian-controlled areas from modern-day Gaza to Lebanon, and letters to supposed equals ("brothers") in states such as Assyria, Babylon, Hittite Anatolia, and Cyprus. Amongst the latter, there is great emphasis on communication through regular embassies and reciprocal greeting gifts, proper hospitality for visiting ambassadors, and occasional marriage alliances.

These interchanges have often been viewed as the ostentatious but distinctive workings of a classic premodern, Maussian economy. In fact, a wide range of studies on both the internal logic of the letters and other documents from the same period now make it clear that much else lies beneath the superficial phraseology (e.g., Liverani 1979, 2003: 123-25; Zaccagnini 1987; also Moran 1987: EA 39). For example, the bullion value of many of the gifts was of great concern, and occasionally less-experienced members amongst the corresponding kings slip into far more market-led discourse. There are counterintuitive, coalsto-Newcastle gifts (e.g., of ivory, ebony, copper, and gold to Egypt), however they may well be meant as explicit requests for the same commodity in return, but at levels commensurate with its greater abundance in the receiver's country. Many of the messengers and ambassadors between kings were also merchants. Some of the gifts were accepted in the spirit of brotherhood and equivalence, but then presented as tribute to an internal domestic population. Gifts may also have initiated a royal audience at which the disembarcation of other accompanying shipments could be discussed.

To revisit Fiske's relational models, these transactions were being coordinated via a logic of matched equivalence, but were also facilitating market-led calculations and were occasionally misrepresented as ranked differences in royal authority. Rulers were clearly aware of potential discrepancies between the phrasing of relationships and their reality. The king of Babylon alludes to this in his Egyptian correspondence when he expresses annoyance that his gift of chariots had been displayed as tribute during an Egyptian parade, and he tries to interfere in his rival's, the king of Assyria's, attempts to initiate relations with Egypt by deliberately drawing an ugly contrast between the two aspects of the process ("gifts" and "purchases"; see Zaccagnini 1987: 58). This veiled language of Bronze Age diplomacy successfully coordinated a range of political, legal, and economic relationships over very long distances, and greeting gifts were an established class of elite objects that were well designed to play flexible roles, as both real gifts between perceived equals of refined cultural sensibility, and bribes or commercial enticements.

I would also go further and argue that not only have we sometimes slightly misread the nature of market-led relationships in the Bronze Age Mediterranean and underestimated the overall amount of commercial activity, but we have also systematically misread the character of royal and/or temple disbursements. The balance of influence between palaces and temples varies significantly in different regions and at different times, with the palace being more of a constant throughout, but they were typically the largest producers, consumers, arbitrators, and patrons of Bronze Age commodities. Their invested wealth, organisational infrastructure, political authority, religious influence, control of taxation, and/or support for key port or caravan facilities often, therefore, 
configured the major patterns of commercial trade. However, this also made the ruler and the gods prime authenticators of commodity brand value. It is no accident that, for example, we see one or more gods as the celebrity guests for the wine festivals at Ugarit, as receivers of votive quantities of perfumed oil at Pylos, as the official guarantor of untampered textile loads at Assur, or as the statuesque overseers of copper production at Enkomi (see below). These were all goods that were primarily traded as marketed commodities, but divine or royal sponsorship was a crucial preliminary act, no doubt treated reverentially and sincerely, but with the longer term effect of endorsing the quality and quantity of the finished products.

In any event, the overarching conceptual metaphor of the family and small village binds together not only diplomacy and commerce, but also certain religious functions. The dwellings of rulers, gods, and traders had much in common semantically and practically. As suggested above, the term "house" had seemingly overlapping meanings that, depending on context, could refer to the household of an individual, a family-based firm, the house of a god (i.e., a temple), or the commercial interface of several of these (e.g., Castle 1992: 250-53; Killen 1979: 176-69; Silver 1995: 3-38; Veenhof 1972: 116, 397-99).

A further important consideration is the fact that even those commodities produced by the palaces and major temples for certain highly charged ceremonial events were not always consumed, permanently stored, or destroyed thereafter. Instead, they leaked out of this superficially closed loop into other circuits, and did so as a matter of course. An evocative example first mentioned by Leo Oppenheim (1964: 183-98) and recently revisited by David Wengrow (forthcoming) is the smoking meat of Egyptian and Mesopotamian ritual that was fed to divine statues incapable of eating it but thereafter reentered the world of circulating goods, imbued with enormous added charisma. John Bennet (2008) also discusses the semi-standardised, prestigious paraphernalia manufactured by the Mycenaean palaces for their elite supporters and notes that they involved materials so wholly infused with a palatial ideology and transformed by palatial craft specialists that we might construe them as a kind of Palace $^{\mathrm{TM}}$, but were nonetheless objects that did eventually leak out into a wider, lower elite world.

The aftermath of ceremonial disbursement is just one instance of the kinds of brand leakage mentioned above as being widely relevant in the operation of distributed economies, and I will return to further examples and other types below. In any case, the choreography of commerce encouraged the resocialisation of commodities in particular ways, and we should therefore look particularly carefully at the way the physical appearance of such commodities, the marks made on them, and the labels attached to them might endorse not only quality and quantity, but also particular kinds of consumer relationship. The physical branding of cattle, sheep, objects, and slaves with the emblematic marks of temple, city, household, or individual ownership is attested from at least the late $3^{\text {rd }}$ millennium BC in Mesopotamia if not before (de Maaijer 2001; Foxvog 1995). 
Evidence for such marking practices occasionally survives in documentary form, but it is worth acknowledging the even greater problems associated with the patchy nature of the archaeological record. The most archaeologically enduring marks on commodities are often those made early on, during production, with those made during the later stages of distribution often being more ephemeral and fragile. Therefore, we are likely to get our strongest apparent evidence for product advertisement for those unusual cases where production and distribution are strongly integrated, such as for a limited range of royal and temple products. The patchy fate of labels and sealings is particularly important here: Clay sealings are only preserved under certain unusual burning conditions, and wax versions will have disappeared entirely. Ink inscriptions are sometimes found in better preserved contexts (particularly in Egypt; see, e.g., Hayes 1951), but their recovery is still incredibly limited and uneven. What the documentary and iconographic evidence does make clear, and what some of the specific examples discussed below also reveal, is that the wrapping and sealing of standardised goods was incredibly widespread and involved not just the treatment of individual items but also packaging in groups, often in very elaborate ways.

The following sections address the relationship between substitutable goods, product marking, and social relationships as they relate to the circulation of four key Mediterranean commodities.

\section{Metals}

Metals are by no means always the highest value items in early complex societies, but a conceptual triad of gold, silver, and bronze (the latter in the form of copper plus tin), is one that develops most clearly in this region from the $3^{\text {rd }}$ millennium BC onwards (e.g., Sherratt and Sherratt 1991: g.2). Since the Bronze Age, a consistent and, to some extent, decisive feature of the Mediterranean economy has been the circulation of such metals in semi-standardised ingot form. There were a wide variety of different Bronze Age ingot shapes, including, buns, chains, rings, bars, and so-called oxhides, all showing some internal variation in weight but typically hovering around one known weight standard or another. This regularity meant that they could be assessed quickly by counting, even if they were often then checked by weighing and thereafter by remelting (see below, also Davies 1973: pl.lv; Dercksen 1996: 57-60).

Palaces and temples were clearly concerned with controlling a portion of the metals trade to safeguard their own production and, ultimately, also to set limits on the degree of access that other individuals might have to such prestige indicators. Some commentators see parts of the Bronze Age in terms of palatial monopolies in this regard, but typically this argument rests on palatial documentary evidence (that unsurprisingly reveals little interest in nonpalatial transactions). It is clear that the degree of palatial involvement did vary from region to region and over time, but there is nonetheless excellent evidence for the circulation of ingots, finished metal goods, and recycled scrap in private hands (Heltzer 1984; Zaccagnini 1984, and for a particularly enlightening Sumerian "dispute" between silver and copper, see Kramer 1963: 265). In any case, the key point I would like to establish below is that, while the restricted 
nature of metals as a resource led to some highly directional and sometimes carefully managed exchanges, the popularity of particular metal commodities, from particular sources and handled by particularly distributors, was something that had a lot to do with their marketing.

Most of the discussion below focuses on copper as a commodity because it is recovered archaeologically in greater quantities than other metals, has been subject to greater analytical scrutiny with regard to provenance, and was commonly used throughout the social hierarchy. However, it is first worth exploring the role of three other metals: gold, silver, and tin.

Gold comes from a limited number of sources in the eastern Mediterranean and Middle East and has further marketable physical properties: It is shiny, easily worked, and showy in the sense that it can be thinly spread over a large area as leaf and does not tarnish (e.g., Renfrew 1986). It is frequently, therefore, caught up in distinctions between mortality and transcendence, often understood as divine flesh, and used to coat cult statues and other objects (e.g., Aufrère 1991: 725-28; Wengrow forthcoming). Although there were gold sources exploited in Anatolia, the north Aegean, and further afield, much of the gold in the Bronze Age eastern Mediterranean and Middle East seems to have come from via Egypt, and Egyptian gold was sometimes further qualified by the names of the different mining districts from which it originated (Kassianidou and Knapp 2005: g.9.1; Lehrberger 1995: esp. g.1; Vercoutter 1959).

Silver was often a more solid, structural component of artefacts and cult images (in some instances, the bones of the gods; see Aufrère 1991: 412-13), with sources in Anatolia, the Aegean and via the Persian/Arabian Gulf (Moorey 1994: 219-20; Wagner et al. 1985). In addition, although gold, silver, and copper were all sometimes used as notional equivalencies for exchange purposes, silver establishes itself as by far the most common referent from the $3^{\text {rd }}$ millennium onwards (Foster 1977: 35; Leemans 1960: 130-31; Powell 1999).

Compared to gold and silver, tin was an even more geographically restricted commodity and, although there may have been some limited (and perhaps early) exploitation of south-central Anatolian and/or central European sources (Pernicka et al. 2003: 160-65; Yener et al. 1993), a good deal of the tin used in the Bronze Age eastern Mediterranean seems to have been brought thousands of kilometres from the mountains of central Asia (Cierny and Weisgerber 2003), along a series of highly attenuated overland, riverine, and maritime routes. We have very little evidence for the early stages of this journey, but documentary and archaeological evidence becomes more available once this commodity reaches the Mesopotamian region.

One set of documents that have proven particularly insightful have been those pertaining to an early $2^{\text {nd }}$-millennium donkey caravan route from Assur across northern Mesopotamia to Kanesh in central Anatolia (see Figure 2.1). This Assyrian trade is discussed in greater detail in the section on textiles below, but the documentary archives from Kanesh and other sites offer clear evidence for 
the steadily increasing price of tin (in silver) as it travelled westwards (Joannes 1991; Veenhof 2003: 115-16; Veenhof and Eidem 2008: 82-83).

Beyond this geographically afforded overall trend, local variations in the exchange rate of tin were common, fairly sizeable, and the source of much commercial speculation. Some of these related to the varying local supply of other metals and other commodities involved in local trades, but politics was a major factor. For example, the kingdom of Mari temporarily gained much better access to tin supplies after a shift in the political of power among its eastern neighbours (including the demise of Assur) and, for a period of a few years in the $18^{\text {th }}$ century $\mathrm{BC}$, was able to buy tin at about half the usual price and thereby set up a whole tournament of Syrian regional diplomacy, as other states jostled for preferred local trading rights (Charpin and Durand 1991; Limet 1985: 16-17).

Tin was primarily valuable in the Bronze Age for alloying with copper to make bronze, which was harder and more durable. Overall, the copper trade was on an entirely different scale to that of gold, silver, and tin, therefore providing us with a much wider scope for analysis. The link between copper and commerce is quite strong: It was the major material used for tools and was commonly traded, recycled, and alloyed. Merchants on the Nile are referred to as being "as busy as copper" (Blackman and Peet 1925: 288), and copper was also a commonly used unit of equivalence (particularly in Egypt; see Janssen 1975: 441-42). A complex range of distinctions were made to describe different grades, types, and sources (Dercksen 1996: 33-47; Moran 1987: EA 33.9-18, EA 40.6-15; Pritchard 1969: 356), that referred, for example, to the copper's purity and colour, shape as an ingot, and whether it was whole or broken up. In the case of the Old Assyrian trade, the finer grades of Anatolian copper were sometimes worth over twice the price in silver of the poorer ones.

Indications of provenance were also particularly important and could involve references to broad regions, mining, areas or distribution points. Copper can be found in a wide variety of different places across the eastern Mediterranean and Middle East, and smaller quantities continued to come from diverse sources throughout the Bronze Age. However, to judge from both the archaeological and documentary evidence, two regions became dominant transregional suppliers: Dilmun/Magan and Alasia. Dilmun refers to the area of modern day Bahrain, whose population was well known for trading in metal and other resources coming up the Persian/Arabian Gulf from Magan (the metal-bearing zone in the al-Hajjar mountains of modern-day Oman) and via Meluhha (the Indus Valley). In other words, Dilmun was an intermediary rather than a primary metal producer, but nonetheless, the documentary sources often adopt the term "Dilmun copper" and suggest its trade was particularly important during the late $3^{\text {rd }}$ and earlier $2^{\text {nd }}$ millennia BC (Leemans 1960: 121-23; Weeks 2003). A second major region associated with copper production area was Alasia (the Troodos mountains of modern-day Cyprus; for a recent discussion of the debate over the location of this place name and the petrographic provenance of the letters from the king of Alasia, see Goren et al. 2003). There are textual references to suggest it begins to become important during the earlier $2^{\text {nd }}$ millennium, although at present this is only obvious archaeologically by the later Bronze Age (Muhly 1996: 49). 
Amongst the range of Bronze Age ingot types, perhaps the best known and most archaeologically obvious is the oxhide ingot (Figure 2.2c). This shape was used for a variety of different metals, but was particularly associated with copper and, from at least the $15^{\text {th }}$ to the $12^{\text {th }}$ century BC; it appears on artefacts, in wallpaintings, and as a discrete sign in certain contemporary scripts (e.g., Linear B). Literally hundreds of actual examples have also been recovered archaeologically over a very wide area of the Mediterranean and beyond, at least as far north as Bavaria and Bulgaria, as far south as Egypt, west to Sardinia. and east to the Euphrates (Gale 1991: g.2; Pulak 1997: 234-5). The weight of these ingots does vary (both in real terms and due to subsequent corrosion), but hovers around the range associated with various eastern Mediterranean talent-weight standards (ca. 27-30 kg; see Pulak 2000: 141-43), and the written documents confirm that this often allowed the ingots to be referred to in counts, with greater precision thereafter achieved through weighing. 

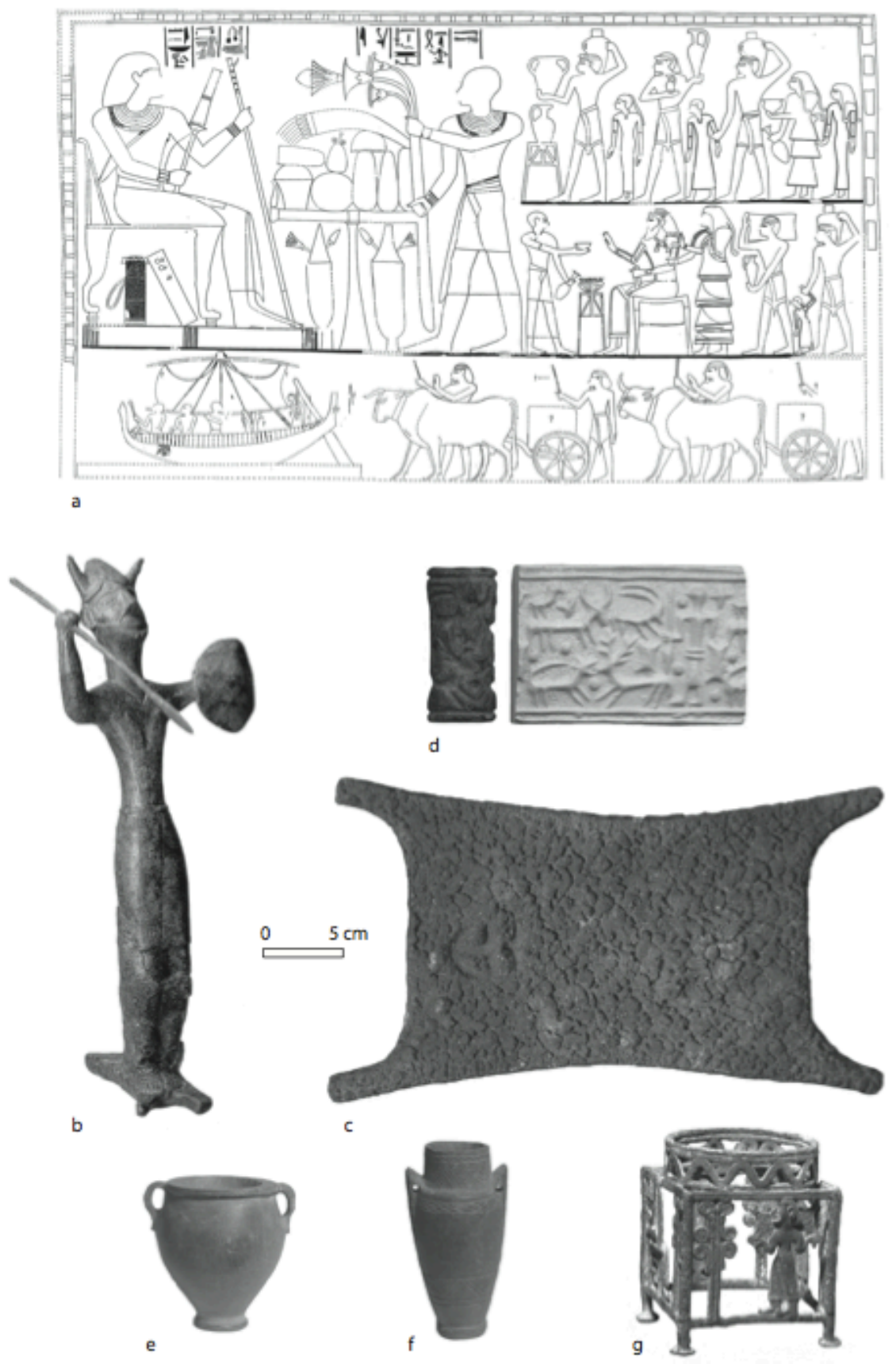

d
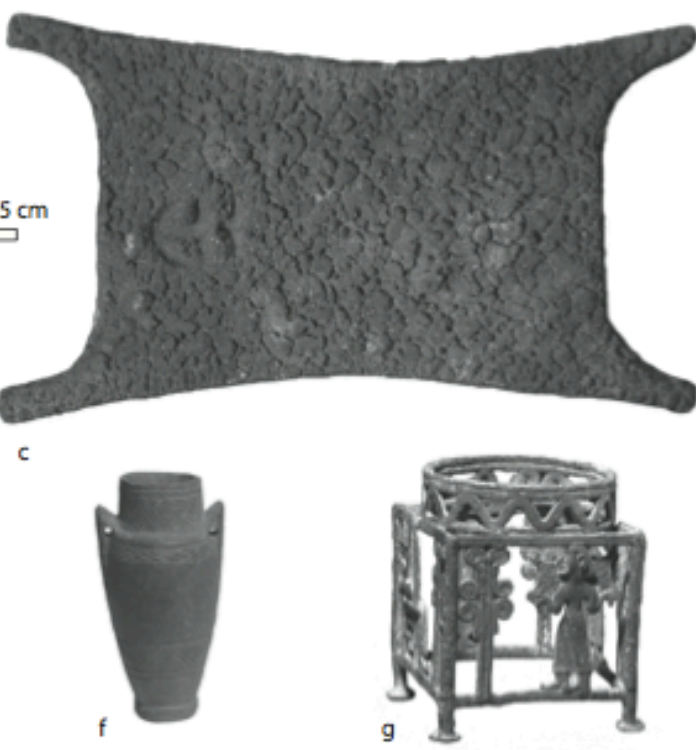

Figure 2.2. Copper and the symbolism of associated commodities: (a) a depic- tion from the tomb of Nebamun (after Säve-Söderbergh 1957: 25-27, pl. xxiii, courtesy of Oxford University Press); (b) a statuette of a (probable) god stand- ing on an oxhide ingot (courtesy of the Department of Antiquities Cyprus); (c) a copper oxide ingot with an impressed stamp (shown at half of the stated scale); (d) a chloritite vessel imitating a metal version; (e) a chloritite vessel with incised decoration; (f) a cylinder seal showing a human figure with spear, oxhide ingots, a bird, a deer, a goat, a dog, an ox, and possible bun/ring ingots (shown at twice the stated scale); and (g) a bronze stand with a figure holding an oxhide ingot. All images not otherwise attributed are courtesy of the British Museum.

This was the right weight for one side of a donkey or that an individual could carry. It was also a shape that could be stacked in a series of overlapping and stable rows in the hold of the ship (e.g., as found on the Uluburun wreck; see Pulak 1998: figs. 4, 12). "Oxhide ingot" is a modern label and it remains far from 
clear whether this symbolic connection also existed in the Bronze Age, but the shape does resemble traditional, semi-standard units of value in the form of animal skins (e.g., the oxhide and the fleece), is occasionally shown in association with live cattle or animal skins (e.g., Tomb of Ramses III: left wall upper; for cattle as another Cypriot export, see Hellbing 1979: 80), or handled in a manner akin to livestock and skins (thrown over the shoulders like a young lamb or calf, underfoot like a floor-covering, or shot at as if hunted, see below).

Lead isotope analysis most commonly sources the copper in many of the ingots to the Cypriot Troodos mountains (e.g., Stos-Gale et al. 1997) and by the later Bronze Age, we see copper oxhide ingots connected with some of the clearest Cypriot religious imagery as well as with other distinctively Cypriot manufactured goods (see below). However, the key point that the discussion below seeks to make is that this trade in Cypriot metal should not be interpreted simply as the export of raw material from a geographically favoured locale but as something that required regular and intensive promotion. There is no inherent reason, for example, why a state such as Egypt should have sought large quantities of copper from Cyprus, given the substantial supplies it had in the Sinai and Eastern Desert. Rather, a crucial factor was the positioning of distinctive commodities (a better way to construe not just elaborate finished metalwork but also the ingots themselves) and the sometimes awkward knitting together of upland landscapes, lowland entrepots, and overseas consumers.

The purity of these ingots (often 99\% copper) implies not just primary smelting, but also a second stage of refinement (Hauptmann et al. 2002; Merkel 1986). However, judging the quality of metal commodities by eye (e.g., purity, internal flaws, etc.) has always been a difficult task (Richardson 2008: 8-11), and issues of verification were clearly a Bronze Age concern. For example, the Babylonian king in one Amarna letter complained about the quality of gold sent to him from Egypt (presumably after he has remelted it) and queried whether it had been inspected prior to departure (Moran 1987: EA 10).

Whole ingots were therefore not always instant indicators of quality and, in fact, freshly broken ones were in many ways more attractive, because they allowed limited inspection of the inside (e.g., Dercksen 1996: 58-59). In this regard, it was not just important that the oxhide ingot was convenient to handle, a visually familiar symbol of value, and of a semi-standard weight, but also that it bore more detailed technological and/or procedural trademarks. The first of these relates to the way the ingots were cast, in an open mould that left the upper side with a characteristic blistered surface (Hauptmann et al. 2002: 4; what would be the "hairy" side if it was, in fact, meant to evoke a real oxhide). This method, combined with the residual impurities in the metal, also meant that the ingots were sufficiently brittle that they could be broken up into smaller units. Given the need to signal that all of these qualities were present in the finished metal commodity, it is no accident that many of the representations of ingots in Bronze Age iconography do not merely depict the shape, but are also careful to show this stippling on one side (e.g., Davies 1973: 21 n.28; Karageorghis and Papasavvas 2003: figs. 1,3$)$. 
A second set of reassuring marks were those cast, impressed or incised on perhaps half of the archaeologically surviving ingots (e.g., Figure 2.2c). As George Bass pointed out (1967: 73), these small marks were value-laden features commonly found on ingots from this point onwards, right through the Classical, Roman, and Medieval periods and up to the present day. In many later instances, they guarantee a certain metal purity, weight, provenance, and/or treatment en route. However, given that not all Bronze Age ingots are marked in any particular archaeological context, it seems more plausible that only one or more amongst a larger batch were being treated in this way. Likewise, different marks were clearly applied at different stages of manufacture and transport (not unlike the distributed marking practices associated with oil and wine containers, see below). Some were designs made in the mould itself or were impressed into the metal while it was cooling, and must therefore be associated with those doing the final refining and casting.

In contrast, the large number of incised marks probably reflects the concerns of the distributor, to identify the source, destination, and/or batchload, or in some limited instances as a temporary tallying mechanism. Marks depicting maritime images such as boats, fish, fishhooks, and tridents (e.g., Pulak 1998: g.10) are quite common and reemphasise (whether deliberately or accidentally) their product's circulation via maritime exchange. What all of this suggests is that we cannot treat Bronze Age ingot marks as immediately analogous to later hallmarks, for example, but instead should arguably see them as just one more conspicuous characteristic of proper trading practice that had both a practical role and a reassuring quality for the end-user.

Casting techniques and ingot marks lead us firmly to the issue of how metals production and trade was organised and who eventually had access to such commodities. Further evidence for the importance of distributors in the metals trade is suggested by the fact that the names associated with metals are often intermediary regions or coastal entrepots rather than the metal-producing areas themselves, hence "tin of Meluhha" or "Dilmun copper" (for a similar situation with Medieval "Damascus steel," see Feuerbach 2006). Likewise, the only known archaeological example of an oxhide ingot mould comes from a coastal entrepot some distance away from any metal-bearing zone (Lagarce et al. 1983: g.15) and the Cypriot sites with the greatest connection to ingot production, rather than primary smelting, are also lowland ports (e.g., Enkomi). The metals trade is also clearly an area of economic activity in which palaces (and temples) are very interested. For example, in a range of documentary sources, we see royal negotiations for shipments of gold, silver, and tin, but also much larger quantities of copper (sometimes involving several tons in one transaction). In various palatial archives, we can also document small to medium-sized disbursements of metal to smiths and careful attention to recovering the value of these as finished objects (e.g., Heltzer 1982: 91-95; Ventris and Chadwick 1973: 509; Wiseman 1953: 105-6). This pattern of involvement with metals has led many commentators to suggest that most new metal passed through the palace economy or leaked out into other circuits indirectly through recycling or tomb robbing (Weeks 2003: 140-42; see also Michailidou 2001; Sherratt 2000). 
However, even leaving aside the eloquent evidence from the Assyrian trade, there is plenty of indication from elsewhere of noninstitutional trades and private ownership of metal bullion (Heltzer 1984; Zaccagnini 1984). A good example from Egypt comes from the late $15^{\text {th }}$-century BC Theban tomb of Nebamun who was a physician and receives an oxhide ingot from a Syrian man, presumably in part payment for his professional help (Figure 2.2a; Wachsmann 1998: 46). A related question, however, is the presence or absence of selforganising, guild-like structures amongst the merchants and craft specialists of this region in the Bronze Age. In a variety of documentary contexts, we have lists of individuals in their professional groupings (and occasionally with their own leaders), but it remains very unclear whether these were just a bureaucratic convenience or whether they actively promoted product quality and identity in the manner that some Medieval guilds seem to have done (e.g., Cutler and Macdonald 1977; Gordon 1956; Ventris and Chadwick 1973: 509; see also Martinon-Torres, this volume; Richardson 2008).

In any case, the Nebamun example is also interesting because, alongside the ingot, both a large Canaanite-style transport jar and a pottery juglet (the latter probably containing perfumed oil) are shown as part of the overall transaction. Similarly, in a letter to his Egyptian counterpart, the Cypriot king requests payment, in large sums of silver, for a shipment of both copper and timber (Liverani 1979: 100-101; Moran 1987: EA 35.27-9). Elsewhere I have suggested that some of these wider, mixed exchanges involving copper implicitly document the intensified commodifcation of a whole upland, ophiolite landscape (also Bevan 2007: 174-79). The broad range of metals, stones, and high biodiversity present within or adjacent to such landscapes made them important sources for a whole range of products in addition to metals, including ultramafic softstones, timber, wildfowl, aromatic plants, and oils and good opportunities for grazing (hence also wool, meat, dairy, and horses). Some of the products were heavily interwoven in terms of their practical uses: Cypriot timber was a natural accompaniment to copper as it provided transport (ships), fuel for metallurgy, and perhaps structural support in mines. Likewise, ultramafic softstones (steatite, chloritite, serpentinite) were variously useful in the metal industry as heat-resistant materials for tuyères, moulds, and/or as finely-carveable stone for seals and vessels (Figure $2.2 \mathrm{~d}-\mathrm{f}$ ).

So, a wide array of products was flowing with the metal out of the Cypriot upland zone and through major coastal entrepots. One interesting aspect of this process is that this mixed assemblage of commodities takes on many consistent symbolic associations, which both acted as propositional devices in a commercial context and as a way of articulating the tensions inherent in such upland/lowland distributed metal economies. The first point to note is divine sponsorship of Cypriot copper production as articulated at lowland centres. Perhaps the most famous examples are bronze statues of (apparently divine) figures standing on oxhide ingots (Figure 2b), but oxhide ingots also appear as miniature votive items (and/or very small bullion units) and there are clear architectural associations between cult activity and copper processing areas at several Cypriot coastal sites (Knapp 1986). 
Beyond these immediately religious associations, oxhide ingots had a wider symbolic capital as targets for Egyptian royal archery contests, as badges of personal wealth and overseas knowledge on Egyptian tomb walls, and as iconic devices shown on other Cypriot craft products such as bronze stands and softstone seals (Figure 2.2d and g; Davies 1935: 49-51, g.4). This contextual promiscuity reflects the proliferation of a highly successful brand sign and its interweaving with a host of related commodities and international activities. In this regard, both the stands and sealstones are worth brief further mention. The former were four sided, often wheeled stands for supporting large metal vessels (Figure 2.2g), and products of advanced metallurgical know-how; several have images of people carrying oxhide ingots (Figure 2.2g); Karageorghis and Papasavvas 2003). Such stands, and at the end of the Bronze Age perhaps iron daggers and knives (see Sherratt 1994), were desirable novelties in their own right that were traded across the eastern and central Mediterranean, but they were also promotional devices that reinforced notions of Cypriot innovation in the metal industry.

Specific types of Cypriot sealstone also show oxhide ingots, in association with plants, animals, and people all plausibly drawn from the same upland landscape in the Troodos mountains of Cyprus (Figure 2.2d; Graziadio 2003; Webb 2002: 118-26, pl.iii.1-8). The material of the seals (chloritite) almost certainly comes from this same general region and was heavily used in the metal industry (see above). As David Wengrow has suggested (2008: 8), seals are well designed to play a dual role "as components of bureaucratic systems and as charismatic signifiers of product identity," and these particular examples record, evoke, and promote the broad range of commodities flowing out of such upland landscapes.

The interesting thing about these distributed economic relationships and extended ophiolite brandings is that they are by no means unique to this region. If we jump backwards in time to the late $3^{\text {rd }}$ millennium $\mathrm{BC}$ and across to the Persian/Arabian Gulf, a strikingly analogous case is provided by the documented flow of copper, timber and other commodities down the Gulf towards the large urban centres of lowland Mesopotamia (Leemans 1960: 121-27; Weeks 2003).2 Some of the products were coming from as far afield as the Indus valley, but many were produced in a region known as Magan, (particularly the ophiolite zone of what is now Oman) and were often shipped by better placed, intermediary traders from Dilmun (from around modern-day Bahrain). In a similar manner to Cyprus, intensified copper trading seems to have stimulated production of a range of ultramafic softstone products, including vessels, talctempered pottery, and moulds, but also the sealstones that Dilmun traders often used as part of their business (Bevan 2007: 175-77, especially fig. 8.21). In both the Cypriot and Dilmun/Magan cases, the symbolism of these ophiolite products expresses a certain Metallschock, oscillating between images of tradition and technical innovation and reflecting a socioeconomic relationship between upland communities, lowland distributors, and overseas consumers that was sometimes

\footnotetext{
2 A wider comparison between the Cypriot and Dilmun/Magan metal trading regimes is the subject of graduate research by Helen Crossman (2007 and an ongoing doctoral project at the University of Reading).
} 
profitable and sometimes traumatic (for other examples of such asymmetry and its consequences, see Shennan 1999).

\section{Textiles}

Reading Gracia Clark's description of Medieval and modern cloth branding practices (this volume) in parallel with Klaas Veenhof's analysis (1972) of textile vocabulary in the Old Assyrian trading colony archives is, in many ways, to visit parallel worlds. In both cases, standardised bolts of cloth (enough to make one if not more full garments) are handled by wholesalers who cater for very specific local tastes. Groups of producers make distinctive products conforming to categories that outside buyers can identify. A clear and widely agreed set of types and quality grades are present and associated with many of these, also indications of provenance (some still meaningful, other long since become notional). Marks on the edges of bolts of cloth, on finished garments, and/or on packets of several textiles are important signifiers of reliable value.

To take the $2^{\text {nd }}$-millennium BC evidence in greater detail (for what follows, see in particular Larsen 1987; Veenhof 1972, 2003), the Assyrian traders mentioned above were shipping tin and textiles westwards from Assur to central Anatolia (see Figure 2.1), sometimes indulging in local Anatolian trade in copper and other items, but ultimately looking to take their profits back to Assur in the form of silver and gold (which were lightweight and highly convertible). These mixed caravans of tin and textiles make an interesting combination. As suggested above, tin was a geographically restricted resource making its way to Anatolia (and beyond) along a trade route thousands of kilometres long. In contrast, the mechanical technology, basic knowhow and raw materials required to produce textiles were common across much of the Mediterranean and Middle East. For textiles, what therefore mattered was the ability of producers and traders to market products in standardised sizes and qualities, with recognised types of wool, distinctive manufacturing techniques, and/or popular types of decoration. In fact, the textiles in the Assyrian caravans heading to Anatolia included many non-Assyrian products that were imported from Babylonia to the south or acquired from nodal communities along the route, but also made locally at Assur.

There were a range of private individuals, partnerships, and institutions (e.g., the ruler of Assur, various temples) who invested in this trade, which involved the movement of large quantities and significant financial returns (conservatively, thousands of textiles, and hundreds of kilograms of profit in silver per year; see Larsen 1987: 51; Veenhof 2003: 70; Veenhof and Eidem 2008: 90). Our documentary sample is, of course, partial, and the texts focus very much on logistical arrangements rather than either the local production or initial purchase of the textiles in Assur or their final sale. Consignments arriving in Anatolia, for example, were entrusted as credit to other traders who were then responsible for marketing them locally. However, while we lack a clear view of the consumer end of the process, there are more than enough clues in the complex choreography of wrapping and sealing these items for transport to suggest that a kind of brand value was very important. 
Both tin and textiles were packaged individually and/or in groups, using a standard cloth wrapping and according to standard approximate weights. Packets of textiles of around $30 \mathrm{~kg}$ each were sealed with hemispherical lumps of clay ("bullae"; see, e.g., Özgüç and Tunca 2001: 135) and placed on either side of the donkey. Other, smaller quantities were stored in top-packs that could be traded or added to en route. The clay lumps were sometimes stamped with the seal of the god and city of Assur as an important guarantee of officially verified quality, type, and quantity (related also to customs tax procedures), but most seals and other marks appear to represent particular individuals and/or their family-firms (Larsen 1977; Veenhof and Eidem 2008: 114-17). The making and breaking of sealings was generally only done at certain times (e.g., not before the end of the journey from Assur) and in front of witnesses: One of its primary roles was to endorse reliable levels of quality, quantity, and type. The proxy use of seals by third parties to stand for physically absent individuals and their family firms also suggests an important role for these as market abstractions, meant to propagate the reliability of a particular firm or of the Assur city trade in general.

This wrapping, marking, and sealing of textiles also occurred at several different levels, with certain procedures associated with textile bundles and others with individual pieces; with some marks or seals to do with the responsibilities of the trader and others to do with the owner and/or producer (Veenhof 1972: 41-44). However, for the individual pieces, a critical zone of attention seems to have been the textile border (sissiktum). In the early $2^{\text {nd }}$ millennium $\mathrm{BC}$, this area of a textile had great metonymic value: For example, the sissiktum was used as an emblem of the person themselves for divorce rituals, as a stand-in for an absent individual in certain haruspical rites, or in lieu of a readily available seal for everyday sealing purposes (Durand 1988: 40; Larsen 1977: 98; van der Toorn 1996: 46-47). Given that the Assyrian caravan trade was often involved in transporting bolts of uncut woven fabric (Veenhof 1972: 89-97), it seems sensible to assume that the term sissiktum could refer to the borders of both finished garments and uncut cloth. ${ }^{3}$ In any case, these were the parts of wrapped textiles that were most visible to the buyer and therefore a key locus for branding activity (G. Clark, this volume).

What sorts of quality differences were such marking practices meant to endorse? The sheer variety of textile terms in the archives attests to a vast array of distinctions based on colour, provenance, finishing, style, and thickness (Veenhof 1972: 144-213). At the very top of the scale, were textiles of so-called royal quality that are referred to not only in the Old Assyrian caravan trade, but also in a range of other Bronze Age textile industries (see below). In some instances, this may literally mean "of or for the king," and thereby refer to royal trade products or those that had somehow found their way into general circulation, but sometimes it just seems to refer to the very finest quality garments. This is a good example of how Bronze Age royal brands might leak out to a wider elite group and will be revisited below with respect to the marketing of high-quality oils.

\footnotetext{
3 Indeed, in more modern cases where particularly prestigious cloth is used, the selvedge is often prominently displayed in the final garment and/or made into a hem (G. Clark, this volume).
} 
In any case, provenance tags were another means of marking out different styles of products in the caravan trade, and thereafter different perceived quality grades. For example, there were clear separations of different Anatolian, Assyrian, and Babylonian-style products. More precisely, the particular case of "Abarnian" textiles is interesting because the name implies a provenance from the town of Abarna, but the texts include at least one reference to these being made by a local Assyrian woman at Assur (Veenhof 1972: 123, 156-58, 191). The Medieval evidence for cloth making is particularly eloquent on such issues (G. Clark, this volume; Richardson 2008: 21-22): The main producing and distributing towns often gave their names to famous products and had a predatory brand quality, swallowing up the products of nearby places, and a key indicator of successful town-brands has been their survival into modern language (e.g., "worsted," "muslin," etc.).

In any case, the import substitution suggested by the Assur-made Abarnian textile is typical of well-placed distributors (see also below for oils), but conversely also a concern for those looking to uphold the value of existing imports. Another good example is a decision by Assur's commercial leaders to put a halt to any trade by expatriate Assyrians in two specific types of local Anatolian textile. This verdict was accompanied by the threat of heavy fines, seemingly because of a fear that the local products were either being marketed more fiercely by Assyrian traders than the actual imports or that they could be converted into cheap imitations (Veenhof 2003: 89-90; and compare with Crăciun, this volume).

The above discussion should make it clear that a whole range of product marking and market-led manipulation was behind the perceived value of these textiles, with good evidence for the kinds of symbolic abstraction that we commonly associate with modern branding practices. While the focus here has necessarily been on the richest body of documentary evidence (given the poor archaeological preservation of textiles), there are signs that such practices were widespread in the Bronze Age eastern Mediterranean. For example, surviving Egyptian linen garments and cut-cloth reveal distinctive border decoration, fringes, and/or defined selvedges (Figure 2.3b-c; Vogelsang-Eastwood 2000; and note the narrative prominence of these in the Middle Kingdom Tale of the Eloquent Peasant; Lichtheim 1975: 169-84). 

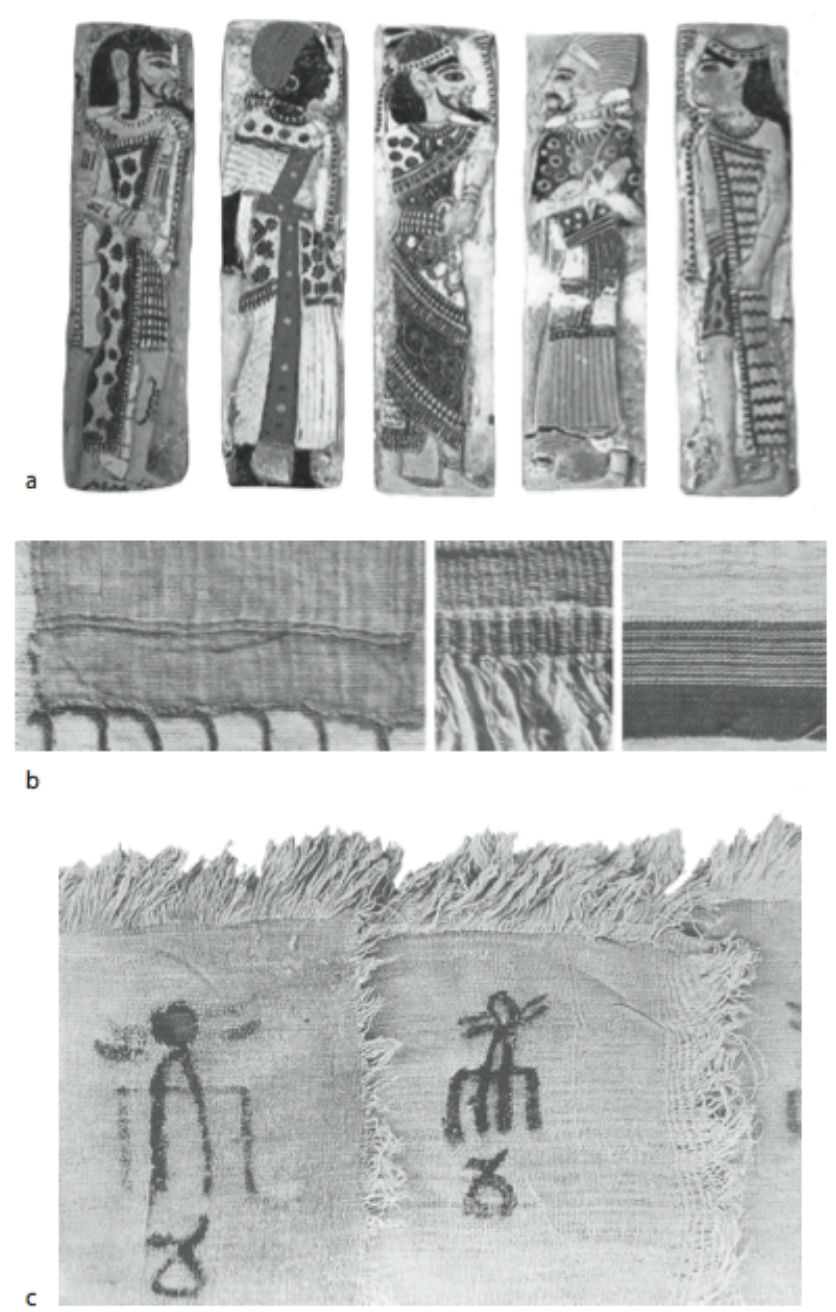

Figure 2.3. Textiles: (a) different dress styles used to mark different ethnic groups on faience plaques from the temple of Ramses III at Medinet Habu (courtesy of Juergen Liepe); (b) edge finishing on Egyptian linen (including, left to right, a self-band, weft fringe and selvedge stripe: van't Hooft et al. 1994: pls. 1.48-9, 2.54, courtesy of the Netherlands National Museum of Antiquities); and (c) inked marks on several Egyptian linen textiles that might refer to the weavers and/or to a local temple (Winlock 1945: pl. xiv. 1-2).

The use of specialist equipment, fixing agents, dyes, splicing, spinning, and weaving techniques ensured distinctive regional products that knowledgeable consumers could recognise, but other manufacturers would struggle to replicate exactly (see Pinheiro-Machado, this volume; Richardson 2008: 17-18), and Egyptian linen preserves good evidence for some of these technological trademarks (e.g., flax splicing, s-spun thread, certain weaves, and weft fringes: van't Hooft et al. 1994: 13-22; also for the special nature of certain Ugaritan dyes, see van Soldt 1990). There are also preserved examples of Egyptian textile marks, including names, dates, and abstract designs that were woven, embroidered, or written in ink onto the borders of the cloth (Figure 2.3c; see also van't Hooft et al. 1994: Table 6a-c).

A variety of activities, involving both first- and second-hand transactions and tomb robbing, seem to have led to the full range of grades and types of both uncut cloth and finished garments being available for potential purchase 
(including those of so-called royal quality: Vogelsang-Eastwood 2000: 293; see also Eyre 1998: 178-83; Janssen 1975: 249-98). Mycenaean and Ugaritan documents suggest a similar pattern of distinctive wool and linen products of various grades, colours, and provenances, with decorated fringes and/or selvedges cut to standard lengths or made into recognisable finished garments (e.g., Killen 1979; Palaima 1991: 291-3; Ribichini and Xella 1985; van Soldt 1990).

Finally, the depictions of garments in wall paintings and decorative reliefs typically combine important categorical or ordinal information about the perceived age, gender, ethnicity, or social class of the wearer with great attention to known quality grades and details of weave, colour, edge finishing, and/or diaphony (e.g., Figure 2.3a; Doumas 1992: nos. 100-34). To a degree, however, we should see these categories and ranks as more sharply defined on the wall (and perhaps in death) than they always were in the home or in the street: For example, the velocity with which foreign cloth and foreign garment styles were circulating suggests that, at least for certain occasions, flexible dressing was an important form of social display, particularly for various lower and upper elite sections of society.

\section{Oil and Wine}

To a large degree, what the manipulation of textile value reflects is the fact that, unlike metals, textiles could be fashioned almost anywhere in the Mediterranean and Middle Eastern region. What therefore mattered was the ability to monopolise and market particular raw materials, processing techniques, and concentrations of skilled labour. Likewise, the desire to acquire particular types of textile, from particular places, was something to be carefully cultivated, by the development of uniquely recognisable techniques, eye-catching styles and attractive symbolic associations, as well as to be reinforced by protectionist strategies if necessary.

Oil and wine products are also heavily processed commodities that could be produced almost anywhere in the Mediterranean, but the way they were promoted differs from textiles in two crucial ways. First, and to varying degrees, they involved an investment in the landscape that might only have a delayed economic return (e.g., vineyards and olive groves that only produced viable harvests several years or decades after initial planting), but once introduced created reuseable landscape capital (e.g., vines, trees, terraces, processing installations, etc.) that encouraged regional specialisation over the longer term, an accompanying inertia resulting from sunk-costs and, potentially, opportunities for evoking the modern equivalent of terroir. Second, oils and wines were liquids that typically required airtight containers for transport and storage, meaning that: (1) The contents themselves were usually hidden from view until the moment of physical consumption; and (2) The containers became as important a locus for product differentiation as the contents. To some extent, however, this section still awkwardly lumps two very different kinds of commodities and glosses over a host of apparent variation in wine types and additives as well as huge variety of oleaginous plants and additives used for different oils. Even so, the discussion below begins by addressing some areas of 
common ground between these commodities and then gradually differentiates them.

In the Bronze Age written records, we regularly see oils and wines with specific names, grades, provenances, ingredients, tastes/scents, etc. Both commodities were loosely associated with acts of appropriate hospitality (though in different ways to family, friends, or strangers) and, in many instances, also the health of the living and dead. Although we can certainly point to overland trade of oil and wine over shorter distances, the long-distance bulk transport of such Bronze Age goods only seems to have been worthwhile around the coastal fringes of the eastern Mediterranean and/or down a few main riverine arteries. Oils and wines were, from at least the later $4^{\text {th }}$ millennium BC onwards, transported in containers of increasingly standardised size and shape, but the trade in these commodities increases during the $3^{\text {rd }}$ millennium $B C$ in tandem with the development of sailing ships (with bigger cargo capacities and longer range than paddled craft; see Broodbank 2000: 96-102; Marcus 2002: 409-12) and becomes a standard feature of Mediterranean life through the rest of the Bronze and Iron Age and up to the present day (note, for example, their central role in the modern global branding of a healthy "Mediterranean" lifestyle; see Meneley 2007).

As with textiles, both oils and wines were often used as markers for specific social classes or ethnic groups as they enabled distinctive cooking, eating, drinking, and ablutionary habits. Within these social categories and communities however, they most often forged, on the one hand, either fairly undifferentiated social relationships built on communal smells, age, and gender-related rites, commensal hospitality, or purity-honour-shame idioms (e.g., for the latter in modern olive oil marketing, see Meneley 2007: 683-84), or on the other, a sense of collegiality and reciprocity through cycling obligations of hospitality (e.g., in welcoming people to a banquet: Davies 1973: pls.lxiii-vii) or the equipment deemed necessary to belong to a certain peer group (e.g., oil and wine consumption "sets," see below).

By the mid-2nd millennium $\mathrm{BC}$, the most obvious example of the take-off of seaborne trade is the maritime transport jar that was used for a wide range of commodities, but especially for oil and wine. "Canaanite-style" amphorae are probably the most famous Bronze Age example (Figure 2.4a), but handled amphorae of one type or another were thereafter the key transport containers for the next 2-3,000 years (until they are supplanted by Medieval staved barrels; see Vroom 2003: 15). As Diane Twede has argued (2002, following Lockhart 1997), transport jar design was consistently driven by the three, near-universal demands of commercial packaging: protection of the contents, utility in transport and consumption, and market communication. While the shape of transport jars was usually a physical adaptation to stacking in and extraction from the holds of ships, their approximate weight when full again often hovers around known standards (the talent weight of $c a$. 27-30 kg mentioned above; see, e.g., Heltzer 1990: 127; or half that for the Mycenaean stirrup jars discussed below), which again probably reflects the need for both individuals and donkeys to carry them efficiently upon disembarkation. 
Canaanite-style jars were first stoppered, then their necks were covered in clay to make them airtight, and thereafter they were typically sealed and/or marked in some other manner (e.g., Grace 1956: g.2b). The sealing practices are typically known to us only through imagery or accidents of archaeological recovery and marking practices are also very unevenly preserved, with inked, painted, or otherwise biodegradeable labels particularly vulnerable. This seriously skews our impression of the amount of both literate and nonliterate information being conveyed with such containers, especially since the multi-purpose, reusable nature of the jar itself ensured that very few of the more archaeologically robust impressed or incised marks are likely to have referred to a singular contents (for these marks, see Hirschfeld 1993, 2002; unsurprisingly they are far from explicit to the uninitiated). However, it is clear again that the Bronze Age sees the beginning of a practice of marking maritime containers that becomes even more common and more clearly propositional in later periods where it is used to endorse standardised amphorae sizes, contents, producers, provenance, and vintage (e.g., Callender 1965; Eiring and Lund 2004; Grace and SavvatianouPetropoulakou 1970: 278-80).

The most obviously branded Bronze Age wines and oils are those that we see associated with restricted spheres of royal (and temple) production. In Egypt, for example, while many private vineyards are depicted in tomb paintings or mentioned in documents, the surviving jar labels typically refer to the products from the large estates of the ruler or major temples. What David Wengrow has pointed out for a very early jar label (2008: 9-10, figs. 1-2) is something that we might consider as a fairly persistent form of Egyptian royal product endorsement: the ruler as both action hero (defeating enemies and running from one corner of the kingdom to another) and fertility figure (giving life to the land; for a modern example with similar tension between roles; see also Holt and Thompson 2004).

Such royal jar labels (and less elaborate ones) certainly imply some indirect benefit to be gained by those who were lucky enough to share in the royal production, but did they ever circulate beyond the seemingly closed loop of royal gifts? In fact, there is a range of evidence to suggest that they did, at least by the later $2^{\text {nd }}$ millennium $\mathrm{BC}$ if not before, and in both first- and second-hand commercial transactions (see below for Ugarit and the Aegean). For Egypt, the situation may initially seem unclear, but we can certainly document the flow of such commodities on the second-hand (and in at least some cases unopened) market, often after first-hand disbursement by the palace and/or temples (Tallet 1998: 260-61). For example, the workers at Deir el-Medina during the $13^{\text {th }}-11^{\text {th }}$ centuries BC seem to have occasionally been given neheh oil (almost certainly olive oil; see Tallet 2004) by royal allocation on particular festivals (unsurprising given the special nature of this community working on royal tomb projects), but some jars are then also exchanged as commodities by the workers amongst themselves (Janssen 1975: 330-42, 350-52).

The case of neheh oil also gives us a rare opportunity to consider a full product trajectory, from manufacture to consumption. The oil was clearly used for a 
range of purposes and $14^{\text {th }}-12^{\text {th }}$-century BC documentary evidence suggests that at that time, a litre was typically worth about $200 \mathrm{~g}$ of copper or $3 \mathrm{~g}$ of silver, whereas wine was both rarer and more costly (following Janssen suggested figures, 1975: 108-9, 330 n.6). However, the dating of the jar labels and other documentary references indicate some important shifts in likely provenance: The earlier examples within the above date range suggest strongly that the contents were imported and microscopic fabric analysis of the actual jars suggests that these were made near the Lebanese and Syrian coasts (Serpico 2004; Smith et al. 2004).

Within this region, the large, cosmopolitan port town of Ugarit is likely to have been one of the major centres of production, especially in the light of the vivid evidence this site has provided for advanced methods of olive oil manufacture (e.g., the lever beam press: Callot 1987), arrangements for bulk export (e.g., harbourside stores of large groups of jars; see Figure 2.4a), the celebration of oils and wines in annual religious events (e.g., Lipinski 1988: 140-42) and their obvious commercial interest to palace, temples and private individuals alike (Bevan 2007: 145-50; Heltzer 1987; Nougayrol et al. 1968: 80-3; Schaeffer 1949: pl.31). However, by the latter half of the $13^{\text {th }}$ century BC, this foreign oil is increasingly replaced by local products from the western Delta: Not only are the jars now often made of local Egyptian clays, but the labels frequently now claim that the oil is "made in Egypt," and one contemporary document notes the coexistence of both Syrian and Egyptian varieties (Tallet 2004: 64-67). 

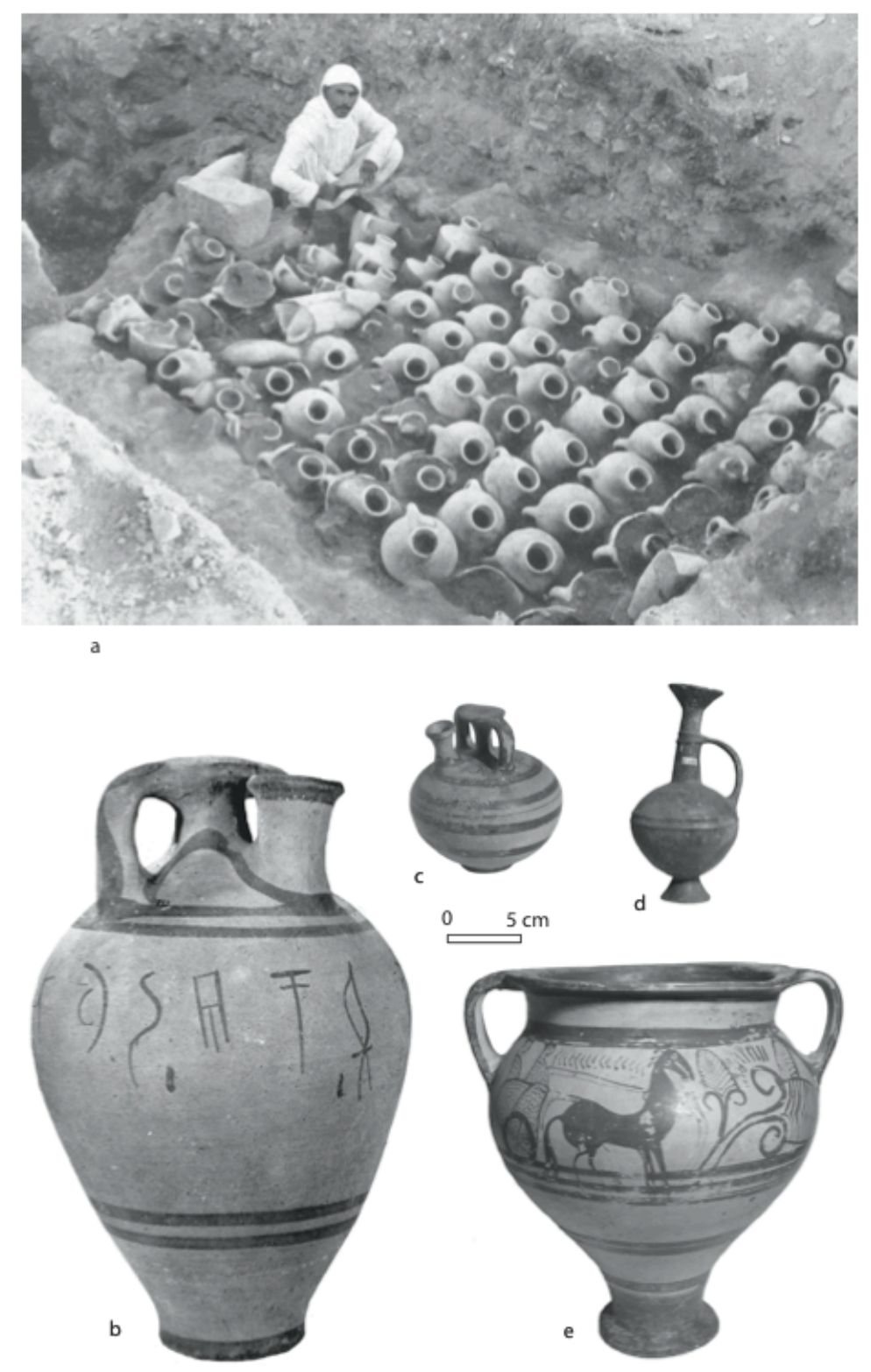

Figure 2.4. Oils, wines, and related liquid commodities: (a) a deposit of over 80 Canaanite-style transport jars from the northern harbour of Ugarit (Schaeffer 1949: pl. ix); (b) a large coarseware stirrup jar painted with Linear B signs (Demakopoulos 1981: 22, courtesy of the 9th Ephorate of Prehistoric and Classical Antiquities, Thebes); (c) a small stirrup jar; (d) a base-ring juglet; and

(e) a mixing bowl decorated with a chariot scene. All images not otherwise attributed are courtesy of the British Museum.

This kind of unusually detailed and converging evidence suggests clear patterns of both production-for-export and deliberate import substitution, just as it also indicates combinations of structured institutional disbursement and commercial circulation. More generally, Bronze Age oils and thicker unguents were made from a range of different oleaginous plants, and different types and grades are an obvious feature amongst the documentary records (Heltzer 1987; Leemans 1960: 14-16; Melena 1983: 109-17; Serpico and White 2000: 390-406; Shelmerdine 1985: 17-39). Oils were used as sources of light, smoke, and general atmosphere in living spaces and they were also comestibles; but the most obvious Bronze Age uses were as perfumed bodily treatments (and related 
to this, sometimes also as treatments of textiles to make them shine and smell like the bodies of the gods; see Shelmerdine 1995). The finest perfumed oils were incredibly complex recipes, made of a mixture of ingredients, whose proper manufacture took many days and required the skills of expert perfumers (e.g., Shimy 1997: 315-67). Perhaps the best example of the elaborate consumption choreography that might be associated with these products are Egyptian prescriptions for "seven sacred oil" sets that were both for anointing living bodies and to allow the deceased to pass through each of the seven gates of the underworld (Gee 1998: Table 7.5; Shimy 1997: 26-119). These oils could be made of purely Egyptian ingredients, purely foreign ones, or a combination, and by the later $3^{\text {rd }}$ millennium at least, each had been given a specific name, place in the anointing ceremony and physical slot in the oil sets themselves, providing a very clear hierarchical ordering of space and time, but ultimately, also a ranking of social relationships amongst the living and the dead.

Beyond this example of upper elite, hyper-crafted oils (and their lower elite simulacra: Roth 1992: fig. 3), there were also a range of others that still involved complex preparation, but were produced in greater quantities and circulated throughout much of the eastern Mediterranean. Broadly speaking, we can distinguish two scales to the trade in oils that first appears in the $3^{\text {rd }}$ millennium, but becomes very clear-cut by the middle of the $2^{\text {nd }}$ millennium $\mathrm{BC}$, one carried out in large coarseware containers and another in decorated juglets. Our degree of clarity about the relationship between these two scales varies with region and context, but the overall suspicion is that the smaller vessels contained more highly processed oils (and other precious liquid products not all of which need have been oil based), allowing particularly well-connected trading centres to add value to broader regional products through elaborate repackaging, extra physical ingredients and perhaps various kinds of ritual endorsement.

While the discussion below returns to one particularly interesting example of product labelling on coarseware containers, it is the smaller, more decorated versions that show the strongest signs of having been heavily marketed commodities. From the middle of the $2^{\text {nd }}$ millennium BC onwards, we see a truly impressive range of decorated juglets being made throughout much of the eastern Mediterranean (typically less than half a litre in volume, but with lots of diversity by type). ${ }^{4}$ These objects exhibit very high levels of stylistic innovation, a range of cultural references (regional styles, different surface treatments and technical allusions), and a tendency towards being substituted for local imitations (e.g., Killebrew 2004; Sherratt 1999).

Their different shapes choreographed pouring in diverse ways and are likely to have had both a gestural and a linguistic vocabulary of appropriate delivery (e.g., the grip taken on differently placed handles, the size and positioning of the spout, with a differentiated terminology similar to, for example, pour, glug, drizzle, or strain in modern English). Moreover, although there was huge variety in juglet styles, most styles exhibit reasonable internal consistency, suggesting that they

\footnotetext{
${ }^{4}$ This juglet phenomenon is only mentioned briefly here but was considered in greater detail by Lesley Bushnell at the conference from which this volume emerged. It is the subject of her doctoral research (University College London) and will be published elsewhere.
} 
were markers for equally recognisable, standardised contents (that need not, of course, all have been oils). Specific styles also seem to have positioned their contents for particular regional markets or particular kinds of consumer: Some may have evoked the contents directly, the most famous but contentious example being those closely resembling a slashed poppy-head because their contents may have been opium based ("base-ring" juglets; see Figure 2.4d; Bisset et al. 1996; Merrillees 1962). Others were metal skeuomorphs and thus intimately connected with class-related aspirations to use higher value metal vessels (Bevan 2007: 136-37), or were burnished-and-incised and thus closer to self-consciously traditional organic designs (e.g., from wood, gourds, basketry, or leather) or perhaps even practices of personal body-marking (e.g., tattoos or body-paint).

The Mycenaean "stirrup-jar" is a good example of the juglet phenomenon (Figure 2.4c). Over perhaps a 400-year period in the later Bronze Age, its external painted decoration is repeatedly modified, with both simple linear designs and sometimes figurative imagery. Some of this variation is regional and contemporary in character, but much of it is chronological, reflecting a high stylistic turnover in decorated Mycenaean pottery more generally that, in modern archaeological terms, has made it one of the finest-grained archaeological indicators for relative chronology in all of world prehistory. The single, narrow spout on stirrup-jars (without a second airhole) makes oil drip out very slowly, and the two strap handles wrapped over a false spout are visually unusual and differentiate the physical act of pouring from that of ordinary juglets. Stirrup jars were also made in much larger, less decorated coarseware versions (Figure 2.4b, with a typical capacity of 12-14 litres), and these seem to have been the main liquid transport jar in the late $2^{\text {nd }}$-millennium Aegean (with oil assumed to be one of the most common contents). The large coarseware versions were a scaling-up of the small, fineware juglets and were arguably less well-adapted to being a maritime transport shape than, for example, the Canaanite-style jar (the latter certainly traded to the Aegean, but was not locally made there and was probably full on arrival rather than traded for its own sake), but they capitalised on the familiar and distinctive qualities of the smaller version.

Although many of the small, decorated stirrup-jars that travelled to the eastern Mediterranean were made in the Argolid, the clays of the larger coarseware transport jars suggest that western Crete was a major production region (Haskell 2004). Large numbers are mentioned in the Linear B documents (e.g., in at least one transaction of 1,800 jars; see Shelmerdine and Bennet 2008: 304), and a group was found stoppered and sealed in a (possible merchant's) store at Mycenae, seemingly ready for onward consignment (Tournavitou 1995: 79-81, pls. 11-12a). Such large coarseware versions certainly were traded beyond the Aegean to both the eastern and central Mediterranean, but are less easily identified in excavations than the more vividly decorated juglets, hence it remains difficult to assess how much breaking-of-bulk was done within the Aegean first. The probable role of Cypriot distributors as well as locals seems likely, however, as many of the jars show incised marks on their handles that 
overlap with those of Cypriot imitations and seem similar in concept to the marks on copper oxhide ingots (Hirschfeld 1993, 2002).

Over 180 such coarseware transport jars also have large painted Linear B signs across the body or on the shoulder (Figure 2.4b; Catling et al. 1980; Haskell 2004), referring to the manufacturer (of the pot and/or of the contents), a probable distributor or owner of some kind, and/or a place name (of manufacture or distribution). Both the clays and the place names suggest that these jars were made in both south-central and western Crete, while the archaeological findspots of these vessels suggest strikingly directional patterns of exportation with each of these two regions supplying different mainland centres (Palaima 1984: 191-94). It is tempting to suggest that bulk oil from Crete was being shipped to the mainland, where it was then enhanced and repackaged for onwards trade in the smaller decorated stirrup jars, but it is worth noting that western Crete was also producing extremely distinctive finewares for export at this time (stirrup-jars for smaller amounts of oil, rhyta for straining liquids, deep bowls for mixing wine; see Kanta 1980: 288-89; Tzedakis 1969), so a more complex picture of the combined marketing of both more and less refined products by several different regional centres seems more likely.

On several of the labelled coarseware jars, the name of the collector/owner is replaced by the adjective "royal." And. as with the textiles and other oils discussed above, we are left to decide whether this implies actual royal control and ownership of the product or something more propositional about the perceived quality of the contents. The abbreviated formulae used for these labels certainly share much in common with those found in the Linear B palace records that deal with bulk commodity transactions (for an overview, van Alfen 1997). However, a traditional interpretation of palatial redistribution, although indicating a key feature of commodity flows, nonetheless frames our understanding of palatial and nonpalatial action in an entirely unsatisfactory way, for at least five reasons.

First, the archives are incredibly partial, reflecting only the subjects recorded in clay, and of those, only the ones preserved by accidental firing. They also reflect only the palace's short-term interest in a very limited range of raw materials, semi-finished, and finished goods (e.g., metals and metalwork, processed oils, textiles, and the ingredients necessary to make them). In fact, there is very little coverage of whole swathes of a Mycenaean kingdom's political, literary, legal, diplomatic, or economic life (e.g., Palaima 1991; and for the importance of assessing these kind of issues of preservation and administrative reach in other Mediterranean and Middle Eastern archives, see Postgate 2001). In fact, the abbreviated vocabulary of palatial administration may well have permeated nonpalatial commodity transactions (as we can see that they did elsewhere in the eastern Mediterranean) but were just less often recorded on clay. Second, the labelled stirrup jars themselves may date to a period after the final collapse of the Mycenaean palace at Knossos and, if true, must be decoupled partially or wholly from models of (at least pan-Cretan) royal administration. Third, oil seems to have been a very secondary concern (to wool and textile production) for the Knossos palace in any case, and it would have been able to acquire the 
amounts mentioned in the archives from its immediate hinterland (Palaima 1984: 201--3), indicating the archaeologically documented scale of oil trade cannot simply be mapped onto palatial production. Fourth, the large size and prominent position of the labelling in a place that was best seen when the jars were not in a hold or stored en masse (i.e., in contrast to the incised marks on the tops of the handles) suggests that their purpose was partly or wholly as a visual enticement. The fact that, in one or two instances, the Linear B signs are so poorly done that the painter may not have been fully aware of their meaning argues in the same direction. Fifth and finally, the Knossos Linear B archive shows the palace acquiring resources from more distant parts of Crete, indirectly, through people that have been given a modern gloss as "collectors/owners" (Bennet 1992). Although the documents certainly do not provide clear-cut evidence about the identity of such people, nevertheless some, if not all, were from the upper elite class, were semi-independent in their operations, and were at least potentially similar to elite traders documented elsewhere in the eastern Mediterranean (Killen 1979: 176-79). What this extended example should also be particularly reminiscent of is the trade in copper, where there are all sorts of coals-to-Newcastle conditions, efforts to endorse qualities and quantities by a range of means, markings at various stages of the production and distribution process, co-marketing of both hyper-elaborate finished goods and less processed versions, possible Cypriot involvement, and mixed political, economic, and religious associations.

The examples above have focused on cases where oil is the most likely contents, but it is worth briefly returning to examples from the wine trade. One general difference between modern wine and that consumed in the Bronze Age is that mixing and removing various additives was a far more important part of Bronze Age wine production, distribution, and consumption routines. Another possible difference is the modern emphasis of curating and ageing wines, with all of the opportunities for biographies of past ownership that this offers (Silverstein 2006: 484). The Bronze Age evidence for the latter practice is equivocal (but see Meeks 1993: 25-26 for a possible 35-year-old wine from the tomb of Thutankhamun, and for a later Homeric tradition of aged and preowned wine, see Iliad VII.467-75, Odyssey II.340, III.391-92, IX.196-215), but they were clearly stored over at least several years and offered the same kinds of opportunities for second-hand circulation (especially for "royal" products), as the neheh oil discussed above.

In Egypt, wine had been imported since perhaps the late $4^{\text {th }}$ millennium, particularly from the area of modern-day Israel-Palestine; but by the middle of the $2^{\text {nd }}$ millennium $\mathrm{BC}$, production within the Nile delta expanded dramatically (Bourriau 2004; McGovern 2003: 85-147). Evidence for both substantial royal and private vineyards exists, but large quantities of wine were also rebottled and relabelled for royal jubilees and other festivals (e.g., McGovern 1997). In a sense, this is a classic example of royal redistribution, but we risk cutting out an important part of these objects' attraction if we ignore their postdisbursement afterlife as royally endorsed products. Egypt's good conditions for archaeological preservation also mean that here, unusually, we have evidence for Egyptianmade, but Canaanite-style transport jars, marked and sealed in a variety of ways 
including pre-firing stamps, ink labels, and mud cones to make the vessels airtight. The legible marks suggest that wine was by far the most common contents in such jars (though see also the neheh oil discussed above) and also often indicate the source and destination for the products, its vintage, vintner, and quantity (e.g., Cerny 1965; Hayes 1951). Different varieties of wine and different quality grades are clearly visible in contemporary New Kingdom Egypt, and such intensification of consumption and diversification of taste also brought with it a variety of novel consumer habits such as decanting into a shallow bowl or sipping through a straw (Meeks 1993: 26-27).

Local eastern Mediterranean wine industries rose and fell as they competed for popularity along the strip from the Egyptian delta to Syria. Given equal opportunities for production in these regions (though less true further east in lowland Mesopotamia where conditions were less favourable; see Powell 1995), it was the ability of producers to cultivate particularly attractive products and a sense of tradition that was important. It is no accident that we see elaborate wine festivals at Ugarit, whose wine production seems to have dwarfed even its production of oil (Lipinski 1988: 140-42). These rituals involved the distribution of large quantities of wine, the involvement of both royal and divine patrons, and the deliberate promotion of Bronze Age terroir, with one poetic text, for example, evoking a "necklace" of terraced vineyards that ringed the Lebanese mountains and were endorsed by the father of the gods, El himself (Watson 1999; for the suggestion that these vineyards were terraced, see Heltzer 1990: 120).

By contrast, although Cretan and Mycenaean palatial states produced a range of wines and traded these within the Aegean (including single transactions of as much as 12-14,000 litres, as well as a range of logo-like, ligatured ideograms, and other adjectival product distinctions; see Palmer 1994, 2000), there is not much evidence for these products circulating more widely in the eastern Mediterranean until the Iron Age. However, what certainly were very popular in the eastern Mediterranean during $14^{\text {th }}-12^{\text {th }}$ centuries BC were highly decorated Mycenaean wine-mixing bowls ("pictorial kraters"; see Figure 2.4e). By this time, metal wine sets were must-have paraphernalia for elite families as a means of confirming their membership of a particular social rank, and within this, of promoting reciprocal behaviour amongst their perceived peers. Pottery versions were, by contrast, some way further down the value hierarchy, and although sometimes also found in high-status contexts, were not formally worthy of mention in royal circles for example. As Sue Sherratt puts it nicely (1999: 195), such pottery therefore "has both less importance and more importance than has often been accorded it": less because it is not something in which the palaces and temples ever expressed any really interest (Whitelaw 2001; in contrast to their high modern valuation by art historians, archaeologists, or the antiquities market) and more because: (1) Both producers and traders clearly valued them enough to trouble to make, copy and distribute them; and (2) The extensive distribution of these vessels restates the fundamental point that transregional trade included a substantial lower and sub-elite component.

In any case, these mixing bowls were probably first made in the north-western Peloponnese of Greece (Schallin 1997), but are in fact more commonly found in 
export contexts elsewhere in the eastern Mediterranean and seem to have been produced with an export market in mind. Indeed, their elaborate decorative scenes of chariot riding, bulls, and wildfowl deliberately evoked a common elite lifestyle throughout much of the north-eastern Mediterranean. There are many other instances of such marketing of apparently nonpalatial pottery products for external markets (the juglets mentioned above being another excellent case), reflecting important feedback between producers distributors and consumers. A further sign of how competitive such a market could be is the fact that by the $13^{\text {th }}-12^{\text {th }}$ centuries BC, near identical mixing bowls were being imitated on Cyprus as local substitutes (Sherratt 1982), to the extent that both import and imitation sometimes appear alongside each other, and local imitations eventually supplant them entirely.

\section{Conclusion}

The above discussion has inevitably mixed general summary with selective detail and no doubt missed many important case studies, but it has sought to explore the making and marking of four Bronze Age commodities-metals, textiles, oils, and wine-at an early stage in their development as familiar components of Mediterranean life. In the Bronze Age, substitutable goods evoked a whole range of quality and quantity distinctions and circulated in networks of gifting, commercial exchange and second- or third-hand transaction that are not always easy to disentangle. However, we do little to further our understanding of the values assigned to such objects, in Bronze Age society or any other, either by uncritically equating them with modern branded goods or by modelling their world as a pre-modern, non-Western other. In fact, just as capitalism as an analytical concept is better divorced from previously wedded notions such as Western democracy or the Protestant work ethic, so, too (and as this edited volume suggests more generally), the concept of commodity branding is better decoupled from any automatic associations with postindustrial, Western capitalism.

To conclude, I would like to suggest two broad areas in which those different regional, thematic, or historical research programmes seeking to address commodities can work most effectively. The first is cross-cultural attention to different scales of brand and different branding agents. Brands themselves exist at various levels of abstraction, from loose ideas and lifestyles, to specific names and places, to the marks on physical products. They can be promulgated by producers, distributors, or consumers and this may involve any combination of individuals, families, factions, communities, corporations, nation-states, and/or divine figures. Therefore, who proposes the new social contexts into which substitutable goods might fit and how is this agency conceived in ideological and practical terms? For modern brands, early analytical emphasis was understandably placed on the defining role of the corporation and of certain kinds of media specialist who were cultural intermediaries (e.g., Negus 2002), but the existence of cheap, fast, global communication networks, and widespread literacy in much of the modern world arguably opens up a whole range of other possibilities that we are only just beginning to comprehend. 
In the Bronze Age, the only entities that seem to have had the capacity regularly to span long-range and otherwise attenuated chains of economic interaction were rulers, certain temple institutions, and the upper elite administrators and traders, and even they did so tenuously and with a bravado that was not always matched by either their practical knowledge of the links in the chain or the forces of commodification and decommodification that they were unleashing. Even so, gods and rulers were key authenticators of Bronze Age value, whether or not the goods involved moved in immediately commercial circuits. Indeed, as with all branded commodities, it was the existence of singular opposites-the goods that the palaces and temples temporarily kept back from circulation-that was arguably crucial (for an excellent ethnographic example of how royal intervention of this kind might be structured, see Warnier, this volume).

A second area of potential common ground is the one raised at the beginning of this chapter: the need for greater attention to the culturally specific but structurally equivalent models through which people coordinate their social relationships. Relational models frequently provide the operational framework by which goods are commodified in the first place, and by which they are later given fresh social meaning. In the Bronze Age Mediterranean and Middle East, social and economic exchanges of all kinds worked within the conceptual framework of appropriate conduct in families and small villages to the extent that even the most seemingly generic commodities were made and marked in ways that cued for their later reintegration into society in a set number of ways. Indeed, without such cues, Bronze Age trade, with its unfamiliar divine and royal endorsements, seemingly irrational behaviours, and endless owls-to-Athens, would make little sense.

\section{References}

Aaker, J. L. 1997. Dimensions of brand personality. Journal of Marketing Research 34:347-56.

Aggarwal, P. 2004. The effects of brand relationship norms on consumer attitudes and behavior. Journal of Consumer Research 31:87-101.

Akerlof, G. 1970. The market for "lemons": Quality uncertainty and the market mechanism. The Quarterly Journal of Economics 84:488-500.

Alberti, M. E. and N. Parise. 2005. Towards a unification of mass-units between the Aegean and the Levant. In R. Laffineur and E. Greco (Eds.), Emporia. Aegeans in the Central and Eastern Mediterranean: 382-91. Liege, Belgium: University of Liege.

Appadurai, A. 1986. Introduction: Commodities and the politics of value. In A. Appadurai (Ed.), The Social Life of Things: 3-63. Cambridge: Cambridge University Press.

Arvidsson, A. 2005. Brands: A critical perspective. Journal of Consumer Culture 5:235-58. 
Aswani, S. and P. Sheppard. 2003. The archaeology and ethnohistory of exchange in precolonial and colonial Roviana. Current Anthropology 44 Supplement:51-78.

Aufrère, S. 1991. L'Univers Minérale dans la Pensée Egyptienne. Paris: Institut Français d'Archéologie Orientale du Caire.

Bass, G. F. 1967. Cape Gelidonya: A Bronze Age shipwreck. Transactions of the American Philosophical Society 57:1-177.

Bennet, J. 1992. "Collectors" or "owners"? An examination of their possible functions within the palatial economy of LMIII Crete. In J.-P. Olivier (Ed.), Mykenaïka. Actes du IXe Colloque International sur les Textes Mycéniens et Egées Organisé pa le Centre de l'Antiquité Greque et Romaine de la Fondation Héllenique des Recherches Scientifiques et l'Ecole Française d'Athenes: 65-101. Paris: Boccard.

Bennet, J. 2008. Palace ${ }^{\mathrm{TM}}$ : Speculations on palatial production in Mycenaean Greece with (some) reference to glass. In C. Jackson and E. E. Wager (Eds.), Vitreous Material in the Late Bronze Age Aegean: A Window to the East Mediterranean World: 151-72. Oxford: Oxbow (Sheffield Studies in Aegean Archaeology 8).

Bevan, A. 2007. Stone Vessels and Values in the Bronze Age Mediterranean. Cambridge: Cambridge University Press.

Beverland, M. B. 2005. Crafting brand authenticity: The case of luxury wines. Journal of Management Studies 42:1003-29.

Bisset, N. G., J. G. Bruhn, S. Curto, B. Holmstedt, U. Nyman, and M. H. Zenk 1996. Was opium known in 18th Dynasty Egypt? An examination of materials from the tomb of the Chief Royal Architect Kha. Agypten und Levante 6:199-201.

Blackman, A. M. and T. E. Peet. 1925. Papyrus Lansing: A translation with notes. Journal of Egyptian Archaeology 11:284-98.

Bourriau, J. 2004. The beginnings of amphora production in Egypt. In J. Bourriau and J. Phillips (Eds.), Invention and Innovation. The Social Context of Technological Change 2. Egypt, the Aegean and the Near East 1650-1150 BC: 7895. Oxford: Oxbow.

Broodbank, C. 2000. An island archaeology of the Early Cyclades. Cambridge: Cambridge University Press.

Callender, M. H. 1965. Roman Amphorae. Oxford: Oxford University Press.

Callot, O. 1987. Les Huileries du Bronze Recent à Ougarit. In M. Yon (Ed.), Le Centre de la Ville. Ras-Shamra-Ougarit III. 38e-44e Campagnes (1978-1984): 197212. Paris: Etudes Recherche sur les Civilisations. 
Castle, E. W. 1992. Shipping and trade in Ramesside Egypt. Journal of the Economic and Social History of the Orient 35:239-77.

Catling, H. W., J. F. Cherry, R. E. Jones, and J. Killen. 1980. The Linear B inscribed stirrup jars and West Crete. Annual of the British School at Athens 75:49-113.

Černy, J. 1965. Hieratic Inscriptions from the Tomb of Tutankhamun. Oxford: Oxford University Press.

Charpin, D. and J.-M. Durand. 1991. La suzeraineté de l'empereur (Sukkalmah) d'Elam sur al Mésopotamie et le "nationalisme" Amorrite. In L. De Meyer and H. Gasche (Eds.), Mésopotamie et Elam: 61-66. Ghent, Belgium: University of Ghent.

Cierny, J. and G. Weisgerber. 2003. Bronze Age tin mines in Central Asia. In A. Giumlia-Mair and F. LoSchiavo (Eds.), The Problem of Early Tin: 23-34. Oxford: Archaeopress.

Crossman, H. 2007. A comparative study of Cyprus and Bahrain, and the Bronze Age trade of copper in the Eastern Mediterranean and Persian Gulf. Master's thesis, University College London.

Cutler, B. and J. Macdonald. 1977. The unique Ugaritic Text UT 113 and the question of "guilds." Ugarit-Forschungen 9:13-30.

Davies, N. d. G. 1935. The work of the graphic branch of the expedition. Bulletin of the Metropolitan Museum of Art 30:49-52.

Davies, N. d. G. 1973. The Tomb of Rekh-mi-re at Thebes. New York: Arno Press.

de Maaijer, R. 2001. Late Third Millennium identifying marks. In W. H. van Soldt (Ed.), Studies Presented to Klaas R. Veenhof on the Occasion of His Sixty-Fifth Birthday: 300-324. Leiden: Netherlands Institute for the Near East.

Demakopoulou, K. 1981. The Archaeological Museum of Thebes Guide. Athens: General Director of Antiquities.

Dercksen, J. G. 1996. The Old Assyrian Copper Trade in Anatolia. Istanbul: Nederlands Historisch-Archaeologisch Instituut.

Doumas, C. 1992. The Wall-Paintings of Thera. London: Thera Foundation.

Durand, J.-M. 1988. Archives Epistolaires de Mari, Volume I.1 of Archives de Mari 26.1. Paris: Editions Recherche sur les Civilisations.

Eiring, J. and J. Lund, Eds. 2004. Transport Amphorae and Trade in the Eastern Mediterranean. Acts of the International Colloquium at the Danish Institute at Athens. Athens: The Danish Institute at Athens. 
Eyre, C. J. 1998. The Market women of Pharaonic Egypt. In N. Grimal and B. Menu (Eds.), Le Commerce dans l'Egypte Ancienne: 173-191. Paris: Institut Français d'Archéologie Orientale.

Fanselow, F. S. 1990. The bazaar economy or how bizarre is the bazaar really. Man 25:250-65.

Feuerbach, A. 2006. Crucible Damascus steel: A fascination for almost 2,000 years. Journal of the Minerals, Metals and Materials Society 58:48-50.

Fiske, A. P. 1991. Structures of Social Life: The Four Elementary Forms of Human Relations. New York: The Free Press.

Fiske, A. P. 2000. Complementarity theory: Why human social capacities evolved to require cultural complements. Personality and Social Psychology Review 4:7694.

Fiske, A. P. 2004a. Four modes of constituting relationships: Consubstantial assimilation; space magnitude, time and force; concrete procedures; abstract symbolism. In N. Haslam (Ed.), Relational Models Theory: A Contemporary Overview: 61-146. Mahwah, NJ: Erlbaum.

Fiske, A.P. 2004b. Relational models theory 2.0. In N. Haslam (Ed.), Relational Models Theory: A Contemporary Overview: 3-25. Mahwah, NJ: Erlbaum.

Fiske, A. P. and N. Haslam. 2000. The four basic social bonds: Structures for coordinating interaction. In M. Baldwin (Ed.), Interpersonal Cognition: 267-98. New York: Guilford.

Foster, B. R. 1977. Commercial activity in Sargonic Mesopotamia. Iraq 39:31 -43.

Foster, R. J. 2005. Commodity futures. Labour, love and value. Anthropology Today 21:8-12.

Foxvog, D. A. 1995. Sumerian brands and branding irons. Zeitschrift für Assyriologie und Vordasiatische Archäologie 85:1-7.

Fuller, T. 1840. A History of the Worthies of England, Volume 2. London: Thomas Tegg.

Gale, N. H. 1991. Copper oxhide ingots: Their origin and their place in the Bronze Age metals trade in the Mediterranean. In N. H. Gale (Ed.), Bronze Age Trade in the Mediterranean: 197-240. Jonsered: Paul Aström.

Gee, J. L. 1998. The requirements of ritual purity in ancient Egypt. (PhD dissertation, Yale University).

Goody, J. 2006. The Theft of History. Cambridge: Cambridge University Press. 
Gordon, C. H. 1956. Ugaritic guilds and Homeric Demiorgoi. In S. S. Weinberg (Ed.), The Aegean and the Near East: Studies Presented to Hetty Goldman on the Occasion of Her Seventy-Fifth Birthday: 136-143. Locust Valley, NY: Augustin.

Goren, Y., S. Bunimovitz, I. Finkelstein, and N. Na'aman. 2003. The location of Alashiya: New evidence from petrographic investigation of Alashiyan tablets from El-Amarna and Ugarit. American Journal of Archaeology 107:233-55.

Grace, V. R. 1956. The Canaanite jar. In S. S. Weinberg (Ed.), The Aegean and the Near East: Studies Presented to Hetty Goldman on the Occasion of Her SeventyFifth Birthday: 80-109. Locust Valley, NY: Augustin.

Grace, V.R. and M. Savvatianou-Petropoulakou. 1970. Les timbres amphoriques Grecs. In P. Bruneau, C. Vatin, U. Bezerra, and D. Meneses (Eds.), Exploration Archéologique de Délos Faite par l'Ecole Française d'Athènes. L'Ilot de la Maison des Comédiens, Volume 25: 277-382. Paris: Boccard.

Graziadio, G. 2003. Il lingotti ox-hide nella glittica cipriota. Studi Micenei ed EgeoAnatolici 45:27-69.

Hamilton, G. G. and C.-K. Lai. 1989. Consumerism without capitalism: Consumption and brand names in late imperial China. In H. J. Rutz and B. S. Orlove (Eds.), The Social Economy of Consumption: 253-279. New York: University Press of America.

Haskell, H. W. 2004. Regional trade patterns in Mycneaean Crete. In S. A. Immerwahr and A. P. Chapin (Eds.), Charis. Essays in Honor of Sara A. Immerwahr: 151-60. Athens: American School of Classical Studies at Athens.

Haslam, N. 2004. Research on relational models: An overview. In N. Haslam (Ed.), Relational Models Theory: A Contemporary Overview: 61-146. Mahwah, NJ: Erlbaum.

Hauptmann, A., R. Maddin, and M. Prange. 2002. On the structure and composition of copper and tin ingots excavated from the shipwreck of Uluburun. Bulletin of the American School of Oriental Research 382:1-30.

Hayes, W. C. 1951. Inscriptions from the palace of Amenhotep III. Journal of Near Eastern Studies 10:35-56.

Heath, D. and A. Meneley. 2007. Techne, technoscience, and the circulation of comestible commodities: An introduction. American Anthropologist 109:593-602.

Hellbing, L. 1979. Alasia Problems. Gothenburg, Sweden: Paul Aström.

Heltzer, M. 1982. The Internal Organization of the Kingdom of Ugarit. Wiesbaden, Germany: Ludwig Reichert. 
Heltzer, M. 1984. Private property at Ugarit. In A. Archi (Ed.), Circulation of Goods in Non-Palatial Context in the Ancient Near East: 161-94. Rome: Edizioni dell'Atene.

Heltzer, M. 1987. Olive growing and olive oil in Ugarit. In M. Heltzer and D. Eitam (Eds.), Olive Oil in Antiquity, Israel and Neighbouring Countries from Neolith to Early Arab Period: 106-120. Padua, Italy: Sargon.

Heltzer, M. 1990. Vineyards and wine in Ugarit. Ugarit-Forschungen 22:119-35.

Hirschfeld, N. 1993. Incised marks (post-firing) on Aegean wares. In C. Zerner (Ed.), Wace and Blegen. Pottery as Evidence for Trade in the Aegean Bronze Age: 309-318. Amsterdam: J. C. Gieben.

Hirschfeld, N. 2002. Marks on pots. Patterns of use in the archaeological record at Enkomi. In J. S. Smith (Ed.), Script and Seal Use on Cyprus in the Bronze and Iron Ages: 49-109. Boston: Archaeological Institute of America.

Holt, D. B. 2002. Why do brands cause trouble? A dialectical theory of consumer culture and branding. Journal of Consumer Research 29:70-90.

Holt, D. B. and C. J. Thompson. 2004 Man-of-action heroes: The pursuit of heroic masculinity in everyday consumption. Journal of Consumer Research 31:425-40.

Janson, A. 2002. The mediatization of consumer culture.Towards an analytical framework of image culture. Journal of Consumer Culture 2:5-31.

Janssen, J. J. 1975. Commodity Prices from the Ramesside Period: An Economic Study of the Village of the Necropolis Workers. Leiden, Netherlands: Brill.

Joannes, F. 1991. L'Etain de l'Elam à Mari. In L. De Meyer and H. Gasche (Eds.), Mésopotamie et Elam: 65-76. Ghent, Belgium: University of Ghent.

Kanta, A. 1980. The Late Minoan III Period in Crete. A Survey of Sites, Pottery and Their Distribution. Gothenburg, Sweden: Paul Aström (Studies in Mediterranean Archaeology 58).

Karageorghis, V. and G. Papasavvas. 2003. A bronze ingot-bearer from Cyprus. Oxford Journal of Archaeology 20:339-54.

Kassianidou, V. and A. B. Knapp. 2005. Archaeometallurgy in the Mediterranean: The social context of mining and trade. In E. Blake and A. B. Knapp (Eds.), The Archaeology of Mediterranean Prehistory: 252-69. Oxford: Blackwell.

Killebrew, A. E. 2004. New Kingdom Egyptian-style pottery in Canaan: Implications for Egyptian rule in Canaan during the 19th and early 20th Dynasties. In G. N. Knoppers and A. Hirsch (Eds.), Egypt, Israel and the Ancient Mediterranean World: 309-43. Leiden, Netherlands: Brill. 
Killen, J. 1979. The Knossos Ld(1) Tablets. In E. Risch and H. Mühlestein (Eds.), Colloquium Mycenaeum: 151-81. Geneva: Librairie Droz.

Knapp, A. B. 1986. Copper Production and Divine Protection: Archaeology, Ideology and Social Complexity on Bronze Age Cyprus. Gothenburg, Sweden: Paul Aström.

Komter, A. 2001. Heirlooms, nikes and bribes: Towards a sociology of things. Sociology 35:59-75.

Kopytoff, I. 1986. The cultural biography of things: Commoditisation as a process. In A. Appadurai (Ed.), The Social Life of Things: Commodities in Cultural Perspective: 64-91. Cambridge: Cambridge University Press.

Kramer, S. N. 1963. The Sumerians: Their History, Culture and Character. Chicago: Phoenix.

Lagarce, J., E. Lagarce, A. Bounni, and N. Saliby. 1983. Les Fouilles a Ras Ibn Hani en Syrie (Campagnes de 1980, 1981, et 1982). Contribution à L'Etude de Quelques Aspects de la Civilisation Ugaritique. Comptes Rendus de l'Academie des Inscriptions and Belles-Lettres 74: 249-90.

Larsen, M. T. 1977. Seal use in the Old Assyrian period. In M. Gibson and R. D. Biggs (Eds.), Seals and Sealing in the Ancient Near East: 89-105. Malibu: Undena.

Larsen, M. T. 1987. Commercial networks in the ancient Near East. In M. Rowlands, M. T. Larsen, and K. Kristiansen (Eds.), Centre and Periphery in the Ancient World: 47-56. Cambridge: Cambridge University Press.

Leemans, W. F. 1960. Foreign Trade in the Old Babylonian Period as Revealed by Texts from Southern Mesopotamia. Leiden, Netherlands: E. J. Brill.

Lehrberger, G. 1995. The gold deposits of Europe. An overview of possible metal sources for prehistoric gold objects. In G. Morteani and J. P. Northover (Eds.), Prehistoric Gold in Europe: Mines, Metallurgy, and Manufacture: 115-144. Dordrecht, Netherlands: Kluwer.

Lichtheim, M. 1975. Ancient Egyptian Literature I. The Old and Middle Kingdoms. Berkeley: University of California Press.

Limet, H. 1985. Les Relations entre Mari et la Côte Mediterranéenne sous le Regne de Zimri-Lim. In E. Gubel and E. Lipinski (Eds.), Phoenicia and Its Neighbours: 13-20. Leuven, Belgium: Peeters.

Lipinski, E. 1988. The socio-economic condition of the clergy in the Kingdom of Ugarit. In M. Heltzer and E. Lipinski (Eds.), Society and Economy in the Eastern Mediterranean, c.1500-1000 B.C.: 125-150. Leuven, Belgium: Peeters. 
Liverani, M. 1979. "Irrational" elements in the Amarna trade. In M. L. Jae (Ed.), Three Amarna Essays, Number 1 in Monographs on the Ancient Near East: 93-106. Malibu: Undena.

Liverani, M. 2000. The Great Powers club. In R. Cohen and R. Westbrook (Eds.), Amarna Diplomacy. The Beginnings of International Relations: 15-27. Baltimore: John Hopkins University Press.

Liverani, M. 2003. The influence of political institutions on trade in the Ancient Near East (Late Bronze Age to Early Iron Age). In C. Zaccagnini (Ed.), Mercanti e Politica nel Mondo Antico: 119-37. Rome: Bretschneider.

Lockhart, H.E.. 1997. A paradigm for packaging. Packages Technology and Science 10:237-52.

Manning, P. 2008. Barista rants about stupid customers at Starbucks: What imaginary conversations can teach us about real ones. Language and Communication 28:101-26.

Marcus, E. 2002. Early seafaring and maritime activity in the southern Levant from prehistory through the Third Millennium BC. In E. C. M. van den Brink and T. E. Levy (Eds.), Egypt and the Levant: Interrelations from the 4th through the early 3rd Millennium BC: 403-417. London: Leicester University Press.

Mauss, M. and E. Durkheim. 1963. Primitive Classification. London: Cohen and West.

McGovern, P. E. 1997. Wine of Egypt's golden age: An archaeochemical perspective. Journal of Egyptian Archaeology 83:69-108.

McGovern, P. E. 2003. Ancient Wine. The Search for the Origins of Viniculture. Princeton, NJ: Princeton University Press.

McGraw, A. P. and P. E. Tetlock. 2005. Taboo trade-offs, relational framing, and the acceptability of exchanges. Journal of Consumer Psychology 15:2-15.

McGraw, A. P., P. E. Tetlock, and O. V. Kristel. 2003. The limits of fungibility: Relational schemata and the value of things. Journal of Consumer Research 30:219-29.

Meeks, D. 1993. La production de l'huile et du vin dans l'Egypte Pharaonique. In M. C. Amouretti and J. P. Brun (Eds.), La Production du Vin et de l'Huile en Mediterranée: 3-38. Athens: Ecole Française d'Athènes (Bulletin de Correspondences Hélleniques Supplement 26).

Melena, J. 1983. Olive oil and other sorts of oil in the Mycenaean Tablets. Minos 18:89-123.

Meneley, A. 2007. Like an extra virgin. American Anthropologist 109:678-87. 
Merkel, J. 1986. Ancient smelting and casting of copper "oxhide" ingots. In M. S. Balmuth (Ed.), Studies in Sardinian Archaeology II: Sardinia in the Mediterranean: 251-64. Ann Arbor: University of Michigan Press.

Merrillees, R. S. 1962. Opium trade in the Bronze Age Levant. Antiquity 36:287 92.

Michailidou, A. 1999. Systems of weight and social relations of "private" production in the late Bronze Age. In A. Chaniotis (Ed.), From Minoan Farmers to Roman Traders. Sidelights on the Economy of Ancient Crete: 87-113. Stuttgart, Germany: Franz Steiner Verlag.

Michailidou, A. 2001. Recording quantities of metal in Bronze Age societies in the Aegean and Near East. In A. Michailidou (Ed.), Manufacture and Measurement. Counting, Measuring and Recording Craft Items in Early Aegean Societies: 85-120. Athens: Boccard.

Miller, D. 2008. The uses of value. Geoforum 39:1122-32.

Molm, L. D., G. Peterson, and N. Takahashi. 2001. The value of exchange. Social Forces 80:159-84.

Moorey, P. R. S. 1994. Ancient Mesopotamian Materials and Industries. Oxford: Oxford University Press.

Moran, W. L. 1987. The Amarna Letters. Baltimore: John Hopkins University Press.

Muhly, J. D. 1996. The significance of metals in the late Bronze Age cconomy of Cyprus. In V. Karageorghis and D. Michaelides (Eds.), The Development of the Cypriot Economy. From the Prehistoric Period to the Present Day: 44-59. Nicosia: University of Cyprus.

Muniz, A. and T. C. O'Guinn. 2001. Brand communities. Journal of Consumer Research 27:412-32.

Negus, K. 2002. The work of cultural intermediaries and the enduring distance between production and consumption. Cultural Studies 16:501-15.

Nougayrol, J., E. Laroche, C. Virolleaud, and C. F. A. Schaeffer. 1968. Ugaritica V. Nouveaux Textes Accadiens, Hourrites et Ugaritiques des Archives et Bibliothèques Privées d'Ugarit. Paris: Institut Français d'Archéologie de Beyrouth.

Oppenheim, A. L. 1964. Ancient Mesopotamia: Portrait of a Dead Civilization. Chicago: University of Chicago Press.

Oppenheim, A. L., R. H. Brill, D. Barag, and A. von Saldern. 1970. Glass and Glassmaking in Ancient Mesopotamia. Corning, NY: Corning Museum of Glass Press. 
Oswald, L. R. 1999. Culture swapping : Consumption and the ethnogenesis of middle-class Haitian immigrants. Journal of Consumer Research 25:303-18.

Ozgüc, N. and 0. Tunca. 2001. Kültepe-Kanis: Sealed and Inscribed Clay Bullae. Ankara: Turkish Historical Society.

Palaima, T. 1984. Inscribed stirrup jars and regionalism in Linear B Crete. Studi Micenei ed Egeo-Anatolici 25:187-203.

Palaima, T. 1991. Maritime matters in the Linear B Tablets. In Laffineur, R. (Ed.) Thalassa. L'Egée Préhistorique et la Mer: 273-310. Liège, Belgium: University of Liège.

Palmer, R. 1994. Wine in the Mycenaean Palace Economy. Liège, Belgium: University of Liège.

Palmer, R. 2000. Wine and viticulture in the Linear A and B texts of the Bronze Age Aegean. In P. E. McGovern, S. J. Fleming, and S. H. Katz (Eds.), The Origins and Ancient History of Wine: 269-285. London: Routledge.

Pernicka, E., C. Eibner, O. Oztunal, and G. A. Wagner. 2003. Early Bronze Age metallurgy in the North-East Aegean. In G. A. Wagner, E. Pernicka, and H.-P. Uerpmann (Eds.), Troia and the Troad. Scientific Approaches: 143-72. Berlin: Springer.

Pinker, S., M. A. Nowak, and J. J. Lee. 2008. The logic of indirect speech. Proceedings of the National Academy of Sciences 105:833-38.

Polanyi, K. 1957. Marketless trading in Hammurabi's time. In K. Polanyi, C. Arensberg, and H. Pearson (Eds.), Trade and Markets in the Early Empires: 12-26. Glencoe, IL: Free Press.

Postgate, J. N. 2001. System and style in three Near Eastern bureaucracies. In S. Voutsaki and J. Killen (Eds.), Economy and Politics in the Mycenaean Palace States: 181-94. Cambridge: Cambridge Philological Society.

Powell, M. A. 1995. Wine and the vine in ancient Mesopotamia. In P. E. McGovern, S. J. Fleming, and S. H. Katz (Eds.), The Origins and Ancient History of Wine: 97122. Luxembourg: Gordon and Breach.

Powell, M. A. 1999. Monies, motives and methods in Babylonian Economics. In J. G. Dercksen (Ed.), Trade and Finance in Ancient Mesopotamia: 5-23. Leiden, Netherlands: Nederlands Instituut voor het Nabije Oosten.

Pritchard, J. B. 1969. Ancient Near Eastern Texts Relating to the Old Testament. Princeton, NJ: Princeton University Press. 
Pulak, C. 1997. The Uluburun Shipwreck. In S. Swiny, R. L. Hohlfelder, and H. Wylde Swiny (Eds.), Res Maritimae: Cyprus and the Eastern Mediterranean from Prehistory to Late Antiquity: 233-62. Atlanta: Cyprus and American Archaeological Research Institute.

Pulak, C. 1998. The Uluburun shipwreck: An overview. International Journal of Nautical Archaeology 27:188-224.

Pulak, C. 2000. The balance weights from the Late Bronze Age shipwreck at Uluburun. In C. F. E. Pare (Ed.), Metals Make the World Go Round. The Supply and Circulation of Metals in Bronze Age Europe: 247-66. Oxford: Oxbow.

Rahmstorf, L. 2006. Zur Ausbreitung vorderasiatischer Innovationen in die frühbronzezeitliche Agäis. Praehistorische Zeitschrift 81:49-96.

Renfrew, A.C. 1986. Varna and the emergence of wealth in later prehistoric Europe. In A. Appadurai (Ed.), The Social Life of Things: 141-68. Cambridge: Cambridge University Press.

Ribichini, S. and P. Xella. 1985. La Terminologia dei Tessili nei Testi di Ugarit. Rome: Consiglio Nazionale delle Ricerche.

Richardson, G. 2008. Brand names before the Industrial Revolution. National Bureau of Economic Research Working Papers (13930).

Roth, A. M. 1992. The pss-kf and the "opening of the mouth" ceremony. Journal of Egyptian Archaeology 78:113-47.

Säve-Söderbergh, T. 1957. Four Eighteenth Dynasty Tombs. Oxford: Oxford University Press.

Schaffer, C. F. A. 1949. Ugaritica II (Missions de Ras Shamra V). Paris: C. Klincksieck.

Schallin, A.-L. 1997. The late Bronze Age potter's workshop at Mastos in the Berbati Valley. In C. Gillis, C. Risberg, and B. Sjöberg (Eds.), Trade and Production in Premonetary Greece: Production and the Craftsman: 73-88. Jonsered: Paul Aström.

Serpico, M. 2004. Natural product technology in New Kingdom Egypt. In J. Bourriau and J. Phillips (Eds.), Invention and Innovation. The Social Context of Technological Change 2. Egypt, the Aegean and the Near East 1650-1150 BC: 96120. Oxford: Oxbow.

Serpico, M. and R. White. 2000. Oils, fat and wax. In P. T. Nicholson and I. Shaw (Eds.), Ancient Egyptian Materials and Technologies: 390-429. Cambridge: Cambridge University Press. 
Shelmerdine, C. W. 1985. The Perfume Industry at Mycenean Pylos. Gothenburg, Sweden: Paul Aström.

Shelmerdine, C. W. 1995. Shining and fragrant cloth in Homer. In J. Carter and S. Morris (Eds.), The Ages of Homer. A Tribute to Emily T. Vermeule: 99-107. Austin: University of Texas Press.

Shelmerdine, C. W. and J. Bennet. 2008. Mycenaean states. Economy and administration. In C. W. Shelmerdine (Ed.), The Cambridge Companion to the Aegean Bronze Age: 289-309. Cambridge: Cambridge University Press.

Shennan, S. J. 1999. Cost, benefit and value in the organisation of early European copper production. Antiquity 73:352 -62.

Shennan, S. J. 2002. Genes, Memes and Human History. London: Thames and Hudson.

Sherratt, A. G. 1993. What would a Bronze Age world-system look like? Relations between temperate Europe and the Mediterranean in later prehistory. Journal of European Archaeology 1:1-57.

Sherratt, A. G. and E. S. Sherratt. 1991. From luxuries to commodities: The nature of Bronze Age trading systems. In N. Gale (Ed.), Bronze Age Trade in the Mediterranean: 351-81. Gothenburg[[spelling??]][[Okay]], Sweden: Paul Aström.

Sherratt, E. S. 1982. Patterns of contact: Manufacture and distribution of Mycenean pottery 1400-1100 BC. In J. G. P. Best and N. M. W. de Vries (Eds.), Interaction and Acculturation in the Mediterranean: 179-95. Amsterdam: B. R. Gruener.

Sherratt, E. S. 1994. Commerce, iron and ideology: Metallurgical innovation in 12th-11th century Cyprus. In V. Karageorghis (Ed.), Cyprus in the 11th Century $B C$ : 59-106. Nicosia, Cyprus: Leventis Foundation.

Sherratt, E. S. 1999. E pur si muove: Pots, markets and values in the second millennium Mediterranean. In J. P. Crielaard, V. Stissi, and G. J. van Wijngaarden (Eds.), The Complex Past of Pottery: Production, Circulation and Consumption of Mycenean and Greek Pottery (Sixteenth to Early Fifth Centuries BC): 163-209. Amsterdam: Gieben.

Sherratt, E. S. 2000. Circulation of metals and the end of the Bronze Age in the Eastern Mediterranean. In C. F. E. Pare (Ed.), Metals Make the World Go Round. The Supply and Circulation of Metals in Bronze Age Europe: 82-98. Oxford: Oxbow.

Shimy, M.A.-H. 1997. Parfums et Parfumerie dans l'Ancienne Egypte (de l'Ancien Empire à la Fin du Novel Empire). Villeneuve d'Asq, France: Septentrion.

Silver, M. 1995. Economic Structures of Antiquity. Westport, CT: Greenwood Press. 
Silverstein, M. 2006. Old wine, new ethnographic lexicography. Annual Review of Anthropology 35:481-96.

Simmel, G. 1900. A chapter in the philosophy of value. American Journal of Sociology 5:179-86.

Smith, L. M. V., J. D. Bourriau, Y. Goren, M. J. Hughes, and M. Serpico. 2004. The provenance of Canaanite amphorae found at Memphis and Amarna in the New Kingdom: Results 2000-2002. In J. Bourriau and J. Phillips (Eds.), Invention and Innovation. The Social Context of Technological Change 2. Egypt, the Aegean and the Near East 1650-1150 BC: 55-77. Oxford: Oxbow.

Stos-Gale, Z. A., G. Maliotis, N. H. Gale, and N. Annetts. 1997. Lead isotope characteristics of the Cyprus ore deposits applied to the provenance studies of copper oxhide ingots. Archaeometry 39:83-124.

Tallet, P. 1998. Quelques aspects de l'economie du vin en Egypte ancienne, au Nouvel Empire. In N. Grimal and B. Menu (Eds.), Le Commerce dans l'Egypte Ancienne: 240-67. Paris: L'Institut Français d'Archéologie Orientale.

Tallet, P. 2004. Les oliveraies du Pharaon au Nouvel Empire. In B. Menu (Ed.), La Dépendance Rurale dans l'Antiquite Egyptienne et Proche-Orientale: 53-75. Paris: L'Institut Francais d'Archeologie Orientale.

Tournavitou, I. 1995. The "Ivory Houses" at Mycenae. London: British School at Athens.

Tuk, M. A., P. W. J. Verlegh, A. Smidts, and D. H. J. Wigboldus. 2009. Sales and sincerity: The role of relational framing in word-of-mouth marketing. Journal of Consumer Psychology 19:38-47.

Twede, D. 2002. Commercial amphoras: The earliest consumer packages? Journal of Macromarketing 22:98-108.

Tzedakis, Y. 1969. L'atelier de ceramique Postpalatial à Kydonia, Bulletin de Correspondences Helléniques 93:396-418.

van Alfen, P. 1997. The LM IIIB inscribed stirrup-jars as links in an administrative chain. Minos 31-32:251-74.

van der Toorn, K. 1996. Family Religion in Babylonia, Syria and Israel. Leiden, Netherlands: E.J. Brill.

van Soldt, W. H. 1990. Fabrics and dyes at Ugarit. Ugarit-Forschungen 22:321-57.

van't Hooft, P. P. M., M. J. Raven, E. H. C. van Rooij, and G. M. Vogelsang-Eastwood. 1994. Pharaonic and Early Medieval Egyptian Textiles. Leiden, Netherlands: Rijksmuseum van Oudheden. 
Veenhof, K. R. 1972. Aspects of Old Assyrian Trade and Its Terminology. Leiden, Netherlands: Brill.

Veenhof, K. R. 2003. Trade and politics in ancient Assur. Balancing of public, colonial and entrepreneurial interests. In C. Zaccagnini (Ed.), Mercanti e Politica nel Mondo Antico: 69-118. Rome: Bretschneider.

Veenhof, K. R. and J. Eidem. 2008 Mesopotamia. The Old Assyrian Period. Fribourg/Vandenhoeck, Freiburg: Academic Press.

Ventris, M. and J. Chadwick. 1973. Documents in Mycenaean Greek. Cambridge: Cambridge University Press.

Vercoutter, J. 1959. The gold of Kush. Kush 7:120-53.

Vogelsang-Eastwood, G. 2000. Textiles. In P. T. Nicholson and I. Shaw (Eds.), Ancient Egyptian Materials and Technology: 268-98. Cambridge: Cambridge University Press.

Vroom, J. 2003. After Antiquity. Ceramics and Society in the Aegean from the 7 th to the 20th Century A.C. A Case Study from Boeotia, Central Greece. Leiden, Netherlands: University of Leiden Faculty of Archaeology.

Wachsmann, S. 1998. Seagoing Ships and Seamanship in the Bronze Age Levant. London: Chatham.

Wagner, G. A., G. Weisgerber, and W. Kroker. 1985. Silber, Blei und Gold auf Sifnos: prähistorische und antike Metallproduktion. Bochum, Germany: Deutsches Bergbau-Museum.

Wallendorf, M. 2001. Literally literacy. Journal of Consumer Research 27:505-11.

Wallerstein, I. 1974. The Modern World-System: Capitalist Agriculture and the Origins of the European World-Economy in the Sixteenth Century. New York: Academic Press.

Watson, W. G. E. 1999. Wonderful wine (KTU I.22: 17-20), Ugarit-Forschungen 31:776-84.

Watts, D. J. and S. H. Strogatz. 1998. Collective dynamics of "small-world" networks. Nature 393:440-42.

Webb, J. M. 2002. Device, image, and coercion: The role of glyptic in the political economy of late Bronze Age Cyprus. In J. S. Smith (Ed.), Script and Seal Use on Cyprus in the Bronze and Iron Ages: 111-54. Boston: Archaeological Institute of America.

Weeks, L. R. 2003. Early Metallurgy of the Persian Gulf. Technology Trade, and the Bronze Age World. Leiden, Netherlands: Brill. 
Wengrow, D. 2008. Prehistories of commodity branding. Current Anthropology 49:7-34.

Wengrow, D. forthcoming "Fleshpots of Egypt": Rethinking "temple economy" in the Bronze Age Mediterranean. In E. Frood, A. McDonald, and R. Parkinson (Eds.), Essays for John Baines. Oxford: Griffith Institute.

Whitehead, H. 1993. Morals, models and motives in a different light: A rumination on Alan P. Fiske's Structures of Social Life, Ethos 21:319-56.

Whitelaw, T. 2001. Reading between the tablets: Assessing Mycenaean palatial involvement in ceramic production and consumption. In S. Voutsaki and J. Killen (Eds.), Economy and Politics in the Mycenaean Palace States: 51-80. Cambridge: Cambridge Philological Society.

Wilk, R. R. 2006. Home Cooking in the Global Village: Caribbean Food from Buccaneers to Ecotourists. Oxford: Berg.

Winlock, H. E. 1945. Slain Soldiers from the Tomb of Nebhepetre Mentuhotpe. New York: Metropolitan Museum of Art.

Wiseman, D. J. 1953. The Alalakh tablets. Liverpool, UK: Tinling.

Yener, K. A., P. B. Vandiver, and L. Willies. 1993. Reply to J. D. Muhly, "Early Bronze Age Tin and the Taurus." American Journal of Archaeology 97:255-64.

Zaccagnini, C. 1984. Transfers of movable property in Nuzi private transactions. In A. Archi (Ed.), Circulation of Goods in Non-Palatial Context in the Ancient Near East: 139-60. Rome: Edizioni dell'Atene.

Zaccagnini, C. 1987. Aspects of ceremonial exchange in the Near East during the Late Second Millennium B.C. In M. Rowlands, M. M. Larsen, and K. Kristiansen (Eds.), Centre and Periphery in the Ancient World: 57-65. Chicago: Oriental Institute. 